\title{
Sex in the Cloister: Behind the Image of the "Criminal Monk" in Ming Courtroom Tales
}

\author{
Wu Junqing \\ University of Liverpool
}

The late sixteenth-century Chinese book market witnessed the emergence of a new type of literature: collections of courtroom tales or gong'an 公案, ${ }^{1}$ written in simple classical language (wenyan 文言) with some colloquial elements, ${ }^{2}$ and sold in cheaply bound editions. These tales were written by anonymous authors and were probably aimed at a broad readership, including people of high to moderate literacy.

These stories contain many types of characters, both good and bad: there are just and wise as well as corrupt and incompetent magistrates; chaste and lustful women; righteous and criminal merchants. But when it comes to Buddhist monks, the portrayal is entirely negative. Not one features, say, as a detective friend of the magistrate, helping to reveal the truth and restore justice. They are always suspected or convicted of crimes, especially sex crimes. Bad Daoist clerics are less common in these stories. This was not because Daoists had a better reputation than Buddhist monks (in fact, there are many late imperial anecdotes about Daoist clerics practicing evil magic). Rather, it was because sex crimes

\footnotetext{
1) There are broader and narrower definitions of the gong'an genre. Patrick Hanan uses the term to refer to stories (including pre-1450 vernacular fictions) in which the judicial conclusion is of central importance. Patrick Hanan, "Judge Bao's Hundred Cases Reconstructed," Harvard Journal of Asiatic Studies 40.2 (1980): 301-23. In this article, gong'an refers specially to the ten or more courtroom tale collections published in the late sixteenth century which have the term gong'an in their title.

2) The language of the earliest collection Baijia gong'an 百家公案, is, however, notably simpler than other gong'an collections: Patrick Hanan, The Chinese Short Story: Studies in Dating, Authorship, and Composition (Cambridge, Mass.: Harvard Univ. Press, 1973), 63-65; Hanan, "Judge Bao's Hundred Cases Reconstructed."
} 
are prominent in these gong'an collections and Buddhist monks, who were supposed to be celibate, were obvious targets of satire.

Anticlerical polemics had existed throughout Chinese history, but such a totally negative portrayal of monks was something new. How should we read these stories of criminal and lecherous monks? One interpretation, which remains popular in mainland Chinese and Taiwanese scholarship, treats them as evidence for a so-called "decline of Buddhism" in the late imperial period-by which is meant either a deterioration in clerical morality and behavior or a decline in Buddhist belief and practice. ${ }^{3}$ I find this interpretation unconvincing. The real explanation of this popular literary image lies elsewhere, in an increased demand for recreational literature, and in growing pressure to confine women to the domestic sphere.

There have been a few introductory works dealing with gong'an stories. ${ }^{4}$ Some scholars have paid particular attention to the tales involving monks. ${ }^{5}$ Shōji Kakuitsu 荘司格一 provides the most detailed account

3) For example, Guo Peng 郭朋, Ming Qing fojiao 明清佛教 (Fuzhou: Fujian renmin chubanshe, 1985), 40; Fojiao shi 佛教史, ed. Du Jiwen 杜繼文 (Beijing: Zhongguo shehui kexue chubanshe, 1993), 513; Huang Chanhua 黃嬂華, Zhongguo fojiao shi 中國佛教史 (Taipei: Xinwenli chubanshe, 1983), fanli; He Qimin 何其敏, Zhongguo Mingdai zongjiaoshi 中國明代宗教史 (Beijing: Renmin chubanshe, 1994), 4; Lin Cuiyao 林璀瑤, “Jian, xie, yin, dao: cong Mingdai gong'an xiaoshuo kan senglü de xingxiang” 奸、邪、淫、盜: 從明代公案小 說看憎侶的形象, Lishi jiaoyu 歷史教育 9-10 (2003): 143-67.

4) For example: Ma Youheng 馬幼恒, “Mingdai gong'an xiaoshuo de banben chuantong” 明 代公案小說的版本傳統, Zhongguo xiaoshuoshi jigao 中國小說史集稿, ed. Ma Youheng (Taipei: Taiwan shibao, 1987); Zhang Guofeng 張國風, Gong'an xiaoshuo manhua 公案小說 漫話 (Taipei:Yuanliu, 1990); Huang Yanbai 黃岩柏, Zhongguo gong'an xiaoshuoshi 中國公案 小說史 (Shenyang: Liaoning renmin chubanshe, 1991), Hu Shiying 胡士瑩, Huaben xiaoshuo gailun 話本小說概論 (Beijing: Zhonghua shuju, 1980), 653. Hu tries to establish a genealogy dating back to the Song and Yuan huaben 話本. This appears to me unconvincing, as the gong'an collections of the late Ming display an entirely different social background and writing style. In modern scholarship, these collections are often studied as a group. Examples of prominent Japanese and Western scholarship are Hanan, "Judge Bao's Hundred Cases Reconstructed"; George A. Hayden, "The Courtroom Plays of the Yuan and Early Ming period," Harvard Journal of Asiatic Studies 34 (1974): 192-22O; Chügoku no kōan shōsetsu 中国の公案 小説, ed. Shōji Kakuitsu (Tokyo: Kenbun Shuppan, 1988); Y.W. Ma, "Themes and Characterization in the "Lung-t'u kung-an"," T'oung Pao 59 (1973): 179-202; "The Textual Tradition of Ming Kung-an Fiction: A Study of The Lung-t'u Kung-an," Harvard Journal of Asiatic Studies 35 (1975): 190-220.

5) For example, Taiwanese scholar Lin Shanwen looks at the image of "vow breaking monks" in Ming novellas (not necessary gong'an tales). Lin Shanwen 林珊妓, “Mingdai duanpian xiaoshuo sengren fanjie gushi tantao” 明代短篇小說之僧人犯戒故事探討, Nanda xuebao 南 大學報 39.1 (2005): 17-36. 
of the literary genealogy of these stories involving monks, ${ }^{6}$ while Karasawa Yasuhiko 唐澤靖彦 looks at the influence of the literary image of the "rapist monk" on actual legal cases. ${ }^{7}$ But one question is left entirely untouched: to what extent did the "rapist monk" image reflect the perception of clergy by contemporaries, both elite and non-elite. Of course, literature cannot be treated as a direct window onto society. But it usually reflects, if only indirectly, aspects of the underlying social realities. I would like to use these gong'an stories as a way into the investigation of late imperial attitudes towards monks, nuns, and women.

\section{The Character and Originality of Late Ming Gong'an Stories}

The majority of the existing late Ming gong'an collections were published in the latter years of the Wanli 萬曆 (1573-1620) and early Tianqi 天啓 reigns (1620-1627). Geographically, they were produced in three commercial publishing centers: Jianyang in Fujian, and Nanjing and Hangzhou in the Jiangnan region. We know little about the authors of these tales. ${ }^{8}$ The late Ming book market was an editor's rather than an author's market: publishers were free to paste together various stories by different authors and sell them as a collection. Depending on how well a work sold, the publisher might decide either to continue it or to edit a new one. ${ }^{9}$ The result was that many stories were recycled in different collections, with some modifications. From the fact that over ten collections were produced within a short period of time, we can infer that this type of story was popular. However, this publishing boom was shortlived and died out soon after the 1620s. Qing gong'an novels differ significantly from these late Ming stories: they are much longer and divided

\footnotetext{
6) Shōji Kakuitsu, Chūgoku no kōan shōsetsu, 384-99.

7) Karasawa Yasuhiko, "Between Oral and Written cultures: Buddhist Monks in Qing Legal Plaints," in Writing and Law in Late Imperial China: Crime, Conflict and Judgment, ed. Robert Hegel and Katherine Carlitz (Seattle: Univ. of Washington Press, 2007), 64-80.

8) There are quite a number of works on the topic of the dating and authorship of courtroom stories. See, for example, Hanan, "Judge Bao's Hundred Cases Reconstructed." I am aware that some collections appeared in different editions, containing a few different stories, but a detailed survey from the perspective of the history of the book is beyond the scope of this article.

9) Richard G. Wang, Ming Erotic Novellas: Genre, Consumption, and Religiosity in Cultural Practice (Hong Kong: Chinese Univ. Press, 2011), 44.
} 
into chapters; chivalrous knight-errant characters play an important role. We cannot regard them as belonging to the same genre. ${ }^{10}$

A full-fledged analysis of the literary history of these late Ming gong'an collections is a subject for another study. But there is one question we need to answer before taking the discussion any further: where did these stories come from? Did the authors invent them from scratch or develop them from older stories? And if the latter, then what were those original stories, in terms of genre and function? Detailed philological judgments, concerning for instance when a certain piece was written and who was/ were the author/authors of a certain collection, are not directly relevant here. But the general question of textual origins must be answered.

Unfortunately, we lack satisfactory studies of the textual derivation of gong'an stories - certainly nothing comparable to the work that has been done on Ming vernacular novellas or huaben 話本. The most prominent English language works are devoted to the collections centered on Judge Bao (a Song Dynasty official who became a legendary figure later), namely the various editions of Baijia gong'an 百家公案 and Longtu gong'an 龍圖公案. ${ }^{11}$ But these works are likely to be atypical, since there had been a pool of Judge Bao lore since at least the Yuan. Thus, the Ming authors of Judge Bao stories might have relied on different literary sources from those used in other gong'an stories. ${ }^{12}$ Besides, Baijia gong'an, the earliest gong'an collection, differs significantly from later collections in terms of language and writing style. Quite a few Chinese language works touch upon the origin of gong'an literature, but a systematic philological study is called for. The best work, so far, has been Shōji Kakuitsu's essay on the textual origin of gong'an literature ${ }^{13}$; its weakness, perhaps, is its lack of attention to the literary style of the gong'an stories and their relationship with other types of fiction.

In what follows, I will try to unravel the possible textual origin of some gong'an stories by comparing them with different types of litera-

\footnotetext{
10) For Qing courtroom tales, see Shōji Kakuitsu, Chūgoku no kōan shōsetsu, 416-зo.

11) Hanan, "Judge Bao's Hundred Cases Reconstructed"; Y.W. Ma "The Textual Tradition of Ming Kung-an Fiction."

12) Y.W. Ma and Patrick Hanan both point out that late Ming Judge Bao gong'an collections contain several stories from the early Judge Bao stories in plays and chantefable (cihua 詞話). Hanan, "Judge Bao's Hundred Cases Reconstructed"; Y.W. Ma, "The Textual Tradition of Ming Kung-an Fiction."

13) Shōji Kakuitsu, Chūgoku no kōan shōsetsu.
} 
ture. I will focus only on the "criminal monk" stories, since the focus of this article is social, not literary history. The Ming and Qing experienced a flowering of fiction, including works written in the classical style (wenyan), the elegant vernacular, and coarse colloquial speech. The traditional view, still commonly held by many Chinese scholars, is that Ming and Qing vernacular fiction was a continuation and development of its predecessors in the Song and Yuan. ${ }^{14}$ This view has been largely superseded. Most scholars now treat the genres developed in the Ming and Qing on their own terms, without building an imaginary textual lineage. For example, W.L. Idema argues that no existing huaben claiming to be earlier can be securely ascribed to the pre-Ming period. ${ }^{15}$

That said, it is also obvious that Ming and Qing fiction writers drew freely on earlier literature of similar or of different genres. ${ }^{16}$ Patrick Hanan has convincingly established that late imperial vernacular fictions often derive, lineally and laterally, from early classical language fiction stories. ${ }^{17}$ Although the gong'an stories studied in this article do not belong to what is termed "vernacular fiction" in English language scholarship (except, perhaps, for the above-mentioned Baijia gong'an), ${ }^{18}$ they too derive from earlier sources. In any case, genre-categorizing is always retrospective. Contemporary authors would not have had a clear idea about what genre they were contributing to. Thus, methods and

\footnotetext{
14) The most prominent example is Lu Xun, who was (and still is) very influential in the study of vernacular literature in China. Lu Xun 魯迅, Zhongguo xiaoshuo shilüe 中國小說 史略 (Shanghai: Shanghai guji chubanshe, 2004). See also Hu Shiying, Huaben xiaoshuo gailun, 653 .

15) Wilt L. Idema, Chinese Vernacular Fiction: The Formative Period (Leiden: Brill, 1974), 50. Patrick Hanan's work is to date the most thorough study of the dating problem. Hanan, The Chinese Short Story; Hanan, "Sung and Yüan Vernacular Fiction: A Critique of Modern Methods of Dating," Harvard Journal of Asiatic Studies 30 (1970): 159-84.

16) Hanan, Idema, and Haft make the point that Ming novella authors often used earlier stories. Wilt Idema and Lloyd Haft, A Guide to Chinese Literature (Chicago: Univ. of Michigan Press, 1997), 215.

17) Hanan, The Chinese Short Story, 170-211; Hanan, "The Early Chinese Short Story: A Critical Theory in Outline," Harvard Journal of Asiatic Studies 40 (1980): 301-23.

18) The categorising of Chinese literature is extremely complicated, and different scholars use different names for different literary genres. Even within a genre, there are many subgenres, often named differently. The term "vernacular" is used by Hanan and Idema for nonclassical tales. Hanan also uses the general term "short stories." John L. Bishop uses the term "colloquial" to refer to the same group of stories: Bishop, The Colloquial Short Story in China, A Study of the San-yen Collections (Cambridge, Mass.: Harvard Univ. Press, 1956).
} 
criteria used in the study of "vernacular fiction" might also be applied to that of the gong'an stories.

What are the sources of the bad monk stories? Many of these stories must have been invented by Ming authors. But others derive from earlier stories, including some written in classical language. Some recurrent themes of the Ming bad monk stories can be found in Song "notes and jottings" or biji 筆記 literature. These stories are always written in pure classical language and are supposed to refer to real events, although authors do not claim full responsibility for their truth.

The most striking example is a story titled "The wife of Wang Wugong” 王武功妻 in the Song biji collection Yijianzhi 夷堅志 by the scholar-official Hong Mai 洪邁 (1123-1202). It relates that a monk sent a present to the wife of Wang Wugong in order to make him believe that they were having a sexual liaison. Wang had his wife arrested for adultery and then divorced her. Upon her release, the monk returned and offered her a job as a sewing lady in the monastery. Abandoned and impoverished, Wang's wife had to accept the offer. The monk then took her to his own dwelling, kept her in the cellar, and raped her. The woman eventually escaped and the monk was punished. She, however, finally died of sadness. ${ }^{19}$ The source of this story is unknown; it could be oral tradition. ${ }^{20}$ This theme was a source of inspiration for many bad monk stories in the Ming. The basic motif-a monk tricking the husband into believing his wife has a lover and thus divorcing her-appears, in different forms, in four stories in three gong'an collections. ${ }^{21} \mathrm{~A}$ monk keeping a woman in a cellar is also a well-known topos. This Yijianzhi story may have inspired those gong'an stories containing similar motifs, but there is no direct textual borrowing from one to the other. The former is written in pure classical Chinese; the latter in simple classical Chinese. In the Yijianzhi story, the name of the female victim is unknown; in the gong'an stories it is given. The dialogues are very concise in Yijianzhi; they are lengthy in the gong'an stories. The means used by the criminal monk to trick the husband vary widely between the various gong'an stories, from sending a present to stealing a shoe. The fate of the female

19) Hong Mai, Yijianzhi (Beijing: Zhonghua shuju, 1981), 902.

20) Hanan, The Chinese Short Story, 186-87.

21) They are Baijia gong'an, Haigangfeng gong'an 海剛峰公案, and Longtu gong'an 龍圖 公案. Longtu gong'an contains two identically-plotted stories. 
victim is also different in different stories-in some she dies, in others she does not. In short, the gong'an stories "only have an outline of the plot in common" with the Yijianzhi story, to invoke Hanan's criterion of genre identity. ${ }^{22}$ We cannot speak of textual derivation.

Another classical language source of the gong'an stories are legal case collections, such as the Yiyuji 疑狺集 by He Ning 和凝 from the Latter Jin 後晉 (936-947), the Zheyu guijian 折獄龜鑒 by Zheng Ke 鄭克, and the Tangyin bishi 棠陰比事 by Gui Wanrong 桂萬榮, both from the Song (960-1279). ${ }^{23}$ Of course, these legal case collections are different in nature to the gong'an stories, and the product of a very different reading culture. They were written as legal textbooks or notes, whose main function was to instruct rather than entertain. ${ }^{24}$ They are categorized under the heading of "legal literature" ( fajia 法家) in the great Qing encyclopedia, the Siku quanshu 四庫全書, whereas the sixteenth-century gong'an

22) Hanan, The Chinese Short Stories, 175.

23) I here list only the stories involving clerics. Yiyuji 疑獄集 (SKQS), 1:10 (李傑覘婦奸: An adulterous Daoist monk tries to get the son of his lover killed by getting her to accuse him being unfilial. This story was later copied and embellished in the Pai'an jingqi 拍案驚奇 by Ling Mengchu 凌蒙初 and the Mingjing gong'an 明鏡公案); 3:9 (德裕泥摸金: An unpopular monk is falsely accused of stealing gold by other monks.); 3:10 (張輅察佛語: Monks swindle money by hiding in a statue of Buddha and talking so as to make people think it is the Buddha who is talking); 4:2-3 (敏中疑無臓: A monk witnesses a woman robbed and murdered. He is frightened and runs away but accidently discovers the victim's body, which leads him to be (wrongly) accused of the murder. It turns out that this monk has some karmic debts from his previous life. This story is not strictly speaking a bad monk story. It is embellished in the Pai'an jingqi); 4:3-4 (張詠勘賊僧: Someone robs and murders a monk and pretends to be him. Again, this story is not strictly speaking about a bad monk). Zheyu guijian yizhu 折獄龜鑑譯注 (Shanghai: Shanghai guji chubanshe, 1983), 130 (李德裕劾僧, the same as 德裕泥摸金 in Yiyuji); 247 (李傑覘婦, the same as 李傑覘婦奸 in Yiyuji); 251 (張輅入穴, the same as 張輅察佛語 in Yiyuji); 301 (俞獻卿執僧, a novice robs and murders his teacher); 441 (張詠勘僧, the same as 張詠勘賊僧 in the Yiyuji). Tangyin bishi 常陰比事 in Sibu congkan xubian 四部叢刊續編 (Taipei: Shangwu yinshu, 1966) shang:2 (向相訪賊錢推求奴, the same as 敏中疑無䁍 in Yiyuji), shang:273-74 (李傑買棺重榮咄箭, the same as 李傑覘婦奸 in Yiyuji and 李傑覘婦 in Zheyu guijian), xia:282-83 (孫登比彈德裕摸金, the same as 德裕泥摸金 in Yiyuji), xia:294 (從事函首乘崖察額, the same as 張詠勘賊僧 in Zheyu guijian). The lone story about an adulterous Daoist monk in courtroom tales: Mingjing gong'an 明鏡公案 in Guben xiaoshuo congkan 古本小說叢刊 (Beijing: Zhonghua shuju, 199o), 2:92-103. The story about monks swindling money by hiding in a Buddha statue was included in the Yiyuji and the Zheyu guijian and it was copied and embellished in the Ming courtroom-tale collection Zhusi gong'an 諸司公案 in Guben xiaoshuo congkan, 4:1960-70.

24) This instructional function is made clear by the author in the preface of Yiyuji, 3: "To assist the governance of the state and [to provide] officials with guidance" 助國家之政 理, 爲卿士之指南. 
collections were not even considered appropriate for inclusion. The cases selected in these collections are presented as real-life incidents, and the focus of each story is on technical problems such as how to expose lies and detect irregularities.

Here is an example from the section "detecting crime" (chajian 察姦) in Zheyu guijian:

When Minister Yu Xianqing was the magistrate of Anfeng in Shouzhou, there was a monk who had accumulated a lot of money from donations. His disciples killed him and had him buried. They announced to the town people: "Our teacher has gone travelling." Xianqing suspected a crime and asked [the disciples]: "Your teacher is a friend of mine. How come that he did not tell me before leaving?" The disciples suddenly looked pale. [Xianqing] thus had them arrested and discovered the buried body. The whole town was shocked. ${ }^{25}$

俞獻卿侍郎, 初爲壽州安豐尉。有僧積施財甚厚, 其徒殺而痤之, 乃告縣曰: “師出遊矣。” 獻卿揣其有奸, 詰之曰: “師與吾善, 不告而去, 何也? ” 其徒色 動。因執之, 得所痤屍。一縣大驚。

The author goes on to explain why the disciples are suspect:

If a monk was rich, he would not go travelling. Even if he planned to travel, he would certainly have prepared clothes and bidden farewell [to his acquaintances]. He would not be like mendicant monks and just leave. What his disciples said was already suspicious. They also looked nervous when being asked. Clearly, there must have been a crime. That was why [Yu Xianqing] had them arrested. Xianqing was indeed good at detecting crimes!

僧之富者, 必不能出遊; 其出遊也, 則必治裝告別, 亦不能如打包僧, 翩然往 也。來告之辭已可疑矣, 被詰之色又可見矣, 有奸灼然, 是故執之。獻卿亦可 謂善察奸也。

The narrative is brief and entirely focused on how the vigilant magistrate Yu Xianqing discovered a murder. It lacks any of the features necessary to qualify it as a "tale": no gruesome details of the killing and no dialogue. The message is straightforward: a magistrate should be vigilant about unusual things.

Late Ming gong'an stories are very different. They develop elaborate plots and downplay the technical details of the case. Here is a story from Lianming gong'an 廉明公案.

25) Zheyu guijian yizhu, 3 o1. 
[Magistrate Huan Zaizhong] dreamt of four watermelons one night. One of them had flower blossoms. He woke up and pondered it. But he could not understand [the meaning of the dream]. The next morning, on his way to visit his superior Superintendent Wang, he saw three monks talking about karmic retribution. When he was back [from the visit], the monks were still there. [Magistrate Huang] noticed that their hair was newly shaved and [their heads] were as green as watermelons. This reminded him of his dream of the night before, and he took the three monks back to his office. [He] asked them: "What are your names, you three?" The oldest one answered: "I, the humble monk, am called Yunwai. These two are called Yunbiao and Yunji. We are all disciples of the same teacher." [Huang] asked again: "Which monastery do you live in?" Yunwai said: "We are all itinerant monks and have no fixed place of abode. We arrived at your town just yesterday and temporarily reside in the Inn of Hou Sizhi at the Eastern gate. We have no intention to live here permanently. [Magistrate Huang] asked again: "You are a group of four. Why did only three come out?" Yunwai said: "We only have three and do not have any other." Magistrate Huang then summoned Hou Sizhi (the innkeeper) and asked: "How many monks came yesterday?" Hou said: "There were three." Magistrate Huang said: "This monk said there were four. Why do you conceal one?" Sizhi said: "There was another monk called Yunzhong. He would like to cultivate [Buddhism] quietly. He is doing seated meditation upstairs and would not like to socialize with people. These three monks asked me not to tell anyone lest people visit him and disturb his "concentrated mind". Magistrate Huang made an excuse to go out and asked his men to bring Yunzhong here. [Huang] saw that he had delicate eyes and eyebrows, looking like a woman. This monk knelt down close to Huang's desk, saying while crying: "Yunzong is a fake name; my real name is Simei. My father is Fenwen. He took me, my mother, and a family member named Zhaobao to the place where he was going to be the magistrate's assistant. We passed a mountain on our journey. I don't know the name of that place. There was not a single soul nearby. These three monks killed my parents and Zhaobao. The sedan chair holders fled away. I was the only one who survived. They forced me to shave my hair to pretend to be a monk [so that I could] travel with them. Half a year has passed since then. I have endured all this and did not take my life. I was hoping to meet an official to report this crime so that my parents' murder can be avenged. And now I can leave this world without hatred." Huang heard this and thought what the three monks had done was indeed abhorrent. He ordered them to receive thirty lashes and then sentenced them to death... ${ }^{26}$

黃在中 $\ldots$ 忽一夜, 夢見四個西瓜, 一個開花, 醒來時方牛夜, 思之, 不知其 故。次早去拜升官王給事, 遇三個和合在路上說因果。及回, 其和佮猶未去。 見其新剃頭, 綠似西瓜一般。因思起夜來之夢, 即帶三和台入衙, 問之曰: “你 三人姓名?”一老的答曰：“小僧名雲外, 他二個名雲表、雲際, 皆同門兄弟也。” 又問之曰：“你住居何寺?”雲外曰：“小僧皆遠方行腳, 各地遊行, 身無定居。

26) Lianming gong'an 廉明公案, in Guben xiaoshuo congkan, juan xia.1253-57. 
昨到本府, 在東門侯思止店下暫住, 並不在此久居也。” 又問之曰：“你四個和 佾, 如何只三個出來? ”雲外曰：“只是三人, 並無別伙。” 黃通府命手下拿侯思 止來, 問之曰：“昨日幾個和佾到你店？”侯思止曰：“三個。”黃通制曰：“這和 佾說有四個, 你瞄起一個怎的? ” 思止曰：“更一個雲中和台, 心好養靜, 只在 樓上坐禪, 不喜與人交接。這三和侣叫我休要與人說, 免人參謁, 惱亂他禪 心。” 黃通判賺出, 即命手下去拿雲中來到。見其眉目美好, 貌若婦人。此和向 即跑近案桌前泣曰：“妾假名雲中, 實名四美。父親賁文, 同妾及母親並一家人 招寶, 將赴任爲典史。到一高嶺處, 不知是何地名, 前後無人, 被這三僧殺死 我父母並招寶三個, 其轎夫各自奔走, 止留妾一人, 被他削髮, 假裝作僧, 流 離道路, 今已牛年。妾忍辱荷生, 正願得見官府, 告明此情, 報父母之冤, 死 無所恨。”黃通府聽說, 見三僧情理可惡, 各發打三十, 擬以死罪 ...

In this story, it is the dream of the magistrate-a supernatural element-which reveals the crime. There is nothing otherwise unusual or suspicious about the three criminal monks. No lesson concerning crimeinvestigation could be learned by other officials. The author then goes on to relate that the girl victim Simei was sent back to her hometown and married a rich merchant. Comparing the classical narrative above with this gong'an story, it is clear that the former is focused on the "crime" whereas the latter is focused on the "tale."

Early legal stories and late Ming gong'an stories also differ greatly in their language, although both are conventionally defined as belonging to the "classical" category; for instance, they always use the literary word yue $曰$ instead of the colloquial term dao 道 for a direct quotation of conversation. ${ }^{27}$ But the "classical style" covers a broad spectrum. Early legal stories are written in standard classical style, whereas gong'an stories are written in what is called simple classical, which has more colloquial elements and is less formal.

To illustrate the difference, I will present an original Song story and its Ming retelling. One is from the above-mentioned Yiyuji, the other from the late Ming courtroom tale collection Zhusi gong'an 諸司公案, published by the well-known Fujianese commercial publisher Yu Xiangdou 余象斗.

In the Latter Jin (936-946), there was an iron Buddha statue in Hualin monastery in Guanshi county, Weizhou [in modern day Hebei]. One day, it was said that the

27) A full discussion of the criteria of gong'an language style is beyond the scope of this article. I here defer to the judgment of Patrick Hanan that it belongs to the simple wenyan style. Hanan, The Chinese Short Story, 63-65. 
iron Buddha could talk... [The town magistrate] sent Zhang Lu and Shang Qian to investigate the truth. Zhang Lu snuck into the monks' room and found an underground passage leading to the bottom of the Buddha's statue. [Zhang] came back and said to Shang Qian that [the monks] had indeed committed the crime of cheating. [Zhang] asked Shang Qian to stand in front of the statue. He himself climbed inside the statue to reproach the monks. Then he had the culprits arrested. The emperor heard about this and had them [the culprits] executed. ${ }^{28}$ 石晉時魏州冠氏縣畫林僧院有鐵佛 ... 一日或雲鐵佛能語 ... 傳張輅請與 (衙將) 佁謙偕行詰其妖狀 … 張輅潛開僧房, 見地穴引至佛座下。回, 謂侣謙曰果犯 法欵矣。乃令謙立於佛前, 輅卻由穴入佛空身中, 庽聲具說僧過。便呵擒治取其 魁首數人。上聞就彼翏之。

There was a stone Buddha in Hualin monastery in Guanshi county, Weizhou... the monk Xingtan plotted with his disciples Xingyuan and Hangu: "This stone Buddha's statue is hollow. If [we] dig an underground passage [leading to the statue] and have someone hide there to pretend that the Buddha is talking, we can attract people from afar to donate money and silk. Our monastery will become rich before long." Within a year, thousands of [rolls] of silk were donated. The magistrate's secretary Zhang Lu was extremely perceptive and insightful. [He] came to see magistrate Zhou and said: "... I suspect that the stone buddha is unable to speak, there must be something hidden inside" ... The magistrate said: "I went to see it with three other officials the other day. The Buddha's hall was very clean and there was nothing hidden in any neighboring rooms either. It was true that there was a voice coming from the Buddha's statue at night. [I guess] it was just possessed by wild fox-demons." Zhang said: "It cannot be fox-demons. All seductive demons are afraid of officials and righteous men. Since the Buddha started talking, many famous people and grand officials have come to pray. Are there not any righteous people and famous officials among them? He [the statue] dared to converse [with all of them]. Which demon can be so bold? Besides, everything [the statue] said was ordinary, nothing special. What he understands, I understand better. What he judges, I judge better. [His words] sounded like those of a bumpkin monk rather than a demon." [The magistrate] thus sent his men to investigate... When [they] came to the third room behind the Buddha hall, [they saw] it was very dark. [They] lit a candle and found a hole under the floorboard. Zhang and another man went down. After walking for over two zhang, [they saw] a ladder. [It led to] the inside of the Buddha's statue. Zhang [went there] and announced loudly: "All monks out there kneel down and listen!" The monks all went on their knees with palms closed. Zhang said: "The stone Buddha cannot talk. You monks hatched this plot. [You] secretly made an underground passage in the rear room and hid people inside the Buddha [to talk]. Then you claimed that it was the Buddha talking. [In this way], you have swindled a lot of money and silk out of gentry and country-folk

28) Yiyuji, 3:10. 
alike. [You then] use the money to buy good clothes and nice food, get drunk, keep servants and mistresses, hang out with the rich and entertain friends. [You] are extremely debauched and [I cannot] even list [all your wrongdoings]. You monks deceive and lead good people astray. You also deceive officials. Your crimes deserve the death penalty. I am the guardian deity in this monastery. Therefore, I am hereby pointing out [your] wrongdoings so that they can be eliminated." All the monks, although feeling suspicious, were so frightened that their faces turned yellow. [They] did not dare to make a noise... ${ }^{29}$

魏州冠氏縣畫林寺, 有一石佛 ... 僧醒潭 ... 因與徒眾醒淵、寒谷等謀曰 : “此石佛 腹中空闊, 若使穴地爲道, 藏人入中, 詐爲佛言 ... 真可誘動十方施捨財帛, 則 我寺興發不難矣.”一年之內, 寺中得獻身帛以千計。主簿張輅 ... 極有明識。來 見周令曰：“... 吾料石佛無言, 中必有弊也。”... 令曰：“吾與三長官日前亦去看 矣。佛堂光淨, 其傍舍皆朗朗無壅。夜間果聲自佛出。但世間那有真佛, 不過 妖狐野怪所托而已。” 張簿曰: “亦非狐怪也。凡妖媚皆畏官星、畏正人。今自 佛言之後, 名公巨卿來往瞻拜, 中間豈無正人名宦? 彼皆敢與酬對, 何怪若此 之大也。況日前所聞之語, 皆平平無奇, 來見瑰異卓見。彼所識者, 我識更 精; 彼所辨者, 我辨更透。只似野僧聲口, 不似怪媚見解也。”... 令手下四處搜 尋。到殿後第三間房, 黑暗無光。以燭入照之, 有穴入地下。張與一皇隸下 去, 約二丈餘路外, 倚一高梯。張登其梯上, 乃即是石佛腹中 ... 簿在佛腹中高 聲喝曰：“眾僧都趾聽審！”僧各合掌跪拜。張曰：“石佛本不能言，你僧詐設詭 謀, 在後房中暗開穴道, 藏人入佛腹, 詐稱佛言, 哄騙士民財帛不計其數。將 去買好衣、置美食、醉醇醪、饜膏梁、蓄侍者、養婆娘、交遊長者、請召朋 情, 百般淫亂, 言不能盡 ... 你眾僧熩惑良民, 欺罔官長, 皆當死罪。我本寺伽 藍, 故指出作惡如此, 可盡殘除之。”嚇得眾僧心疑面黃, 不敢出聲 ...

The second narrative is expansive and colloquial. Zhang's speech includes vulgar expressions such as "keeping mistresses" (yang poniang 養婆娘), which are in keeping with the Ming literary image of the "lecherous monk." The phrase "deceiving and leading the good people astray" (shanhuo liangmin 净惑良民) is a contemporary stock accusation levelled at persecuted religious groups. Furthermore, colloquial personal pronouns such as wo 我 (I) and $n i$ 你 (you) are frequently used in the second story: "I am the guardian deity of this monastery" 我本寺伽藍 and "You monks hatched this plot" 你僧詐設詭謀. The Yiyuji story is concise and formal. It contains only facts necessary to form a legal verdict: the talking Buddha, the investigation, and the revelation of the truth. It uses neither wo nor ni; indeed, it often omits the sentence subject altogether-a common feature of the pure classical style. For example, one sentence runs: "[Zhang] Returned, said to Shang Qian that

29) Zhusigong'an in Guben xiaoshuo congkan, 4:196o-7o. 
[the monks] had indeed committed a crime of cheating” 回, 謂俈謙曰 果犯法欵矣.

How should we describe the relation between these two texts? There is no direct borrowing from one to the other-not even of dialogue, the element which, according to Hanan, was most often retained when classical narratives were recomposed in late imperial vernacular stories. ${ }^{30}$ The only textual borrowing concerns the location of the story and the name of the main character.

It is clear now that the relationship between late Ming gong'an literature and early classical narratives is a loose one. It is only bare plot outlines, or sometimes mere motifs, which are passed on from one to the other. Moreover, the proportion of "bad monk," and especially "rapist monk" stories in early biji literature is very low. "The wife of Wang Wugong" is the only example of a "rapist monk" story in Yijianzhi. In earlier legal case collections, stories about wicked monks are very rare as well. In Tangyin bishi, only four out of a hundred and nine cases are about bad monks. "Lecherous monk" stories are almost non-existent. This paucity is in stark contrast to the overwhelmingly negative portrayal of clerics and the large number of "rapist monk" stories in late Ming gong'an tales. Of all the tales involving rape, more than a third feature monks. ${ }^{31}$ All rapist monk stories are repeated in more than one collection. The great popularity of this subject is evident.

Song and Yuan anthologies of short stories provided another source of inspiration for our gong'an stories. Here again, however, we find very few lecherous or rapist monks. The Lüchuang xinhua 綠窗新話, a Southern Song anthology of short stories, contains only two stories (out of over a hundred) with a "criminal monk" theme. One is about a Daoist (rather than Buddhist) monk who has an affair with a widow; her son disapproves of the relationship and tries to end it. The enraged Daoist monk and the widow try to get rid of the son by (falsely) accusing him of ill-treating his mother. The magistrate discovers the truth and has the

\footnotetext{
30) Hanan, The Chinese Short Stories, 175.

31) Based on Huang Wanning 黃琬窩, “Tongsu de xingbaoli: Wanming gong'an xiaoshuoji de shuxie fengge” 通俗的性暴力: 晚明公案小說集的書寫風格, M.A. diss., Qinghua Univ., 2008. The ten collections are: Zhusi gong'an, Lianming gong'an, Xinmin gong'an 新民公案, Longtu gong'an, Baijia gong'an, Haigangfeng gong'an, Xiangqing gong'an 詳情公案, Lütiao gong'an 律條公案, Xiangxing gong'an 詳刑公案, Shenming gong'an 神明公案, and Mingjing gong'an.
} 
widow and monk punished. ${ }^{32}$ This story first appeared in the abovementioned legal case collection Yiyuji and was frequently recycled before the Ming. It was selected for inclusion in the Xin Tangshu 新唐書, compiled in the early Song, and two of the above-mentioned Song legal textbooks: the Zheyu guijian and the Tangyin bishi. ${ }^{33}$ Although it attracted the attention of gong'an authors, the story was no longer narrated in the original simple, matter-of-fact way, but in an elaborate, dressed-up style. The same story, with a few adjustments, can be found in several Ming vernacular works. It appears, for instance, in the short story collection Paian jingqi 拍案驚奇 by Ling Mengchu 凌猛初 ${ }^{34}$ and also in the gong'an collection Mingjing gong'an 明鏡公案. ${ }^{35}$

The other lecherous monk story in the Lüchuang xinhua runs as follows: a monk named Liaoran maintained a long-term sexual liaison with the prostitute Xiunu. When Liaoran finally ran out of money, Xiunu turned him out. This enraged Liaoran so much that he killed her during an argument. The case is allegedly solved by the famous poet-official $\mathrm{Su}$ Shi 蘇軾 (1037-1101). ${ }^{36}$ This story, again, was recomposed in late Ming times. It appears in one of our gong'an collections, ${ }^{37}$ the seventeenthcentury short story collection Sengni niehai 僧尼擎海, and in one of Feng Menglong's 馮夢龍 short story collections, the Huanxi yuanjia 歡 喜冤家, in a more elaborate version. ${ }^{38}$

A later (probably Yuan) fiction anthology, Zuiweng tanlu 醉翁談錄 by Luo Ye 羅燁 contains three stories (out of over fifty surviving stories) about lecherous monks, of which two are about criminal or rapist monks, including the above-mentioned Liaoran story in Lüchuang xinhua. ${ }^{39}$ Another very brief narrative (hardly a story) is about a monk raping a child nun. ${ }^{40}$ The third story is interesting: a monk was caught having an affair with a woman by her husband. The latter extorted

\footnotetext{
32) Fengyue zhuren 風月主人, Lüchuang xinhua 綠窗新話 (Taipei: Shijie shuju, 1958), 61.

33) Xin Tangshu (Beijing: Zhonghua shuju, 1975), 128:4461. For the same story in Zheyu guijian and Tangyin bishi, see footnote 23.

34) Lin Mengchu, Pai'an jingqi (Shanghai: Shanghai guji chubanshe, 1985), 17:5-42.

35) Mingjing gong'an in Guben xiaoshuo congkan, 2:92-103.

36) Lüchuang xinhua, 62 .

37) Lianming gong'an in Guben xiaoshuo congkan, juan shang:1087-9o.

38) Feng Menglong, Huanxi yuanjia 歡喜冤家 in Guben xiaoshuo jicheng 古本小說集成 (Shanghai: Shanghai guji chubanshe, 1994), 37-48.

39) Luo Ye, Zuiweng tanlu, Guanlange 觀瀾閣 reprint (Tokyo, 1940), juan 2: gengji 7-8.

40) Ibid., juan 2: gengji 8-9.
} 
money from the monk and castrated him. However, the story has a happy ending. The monk, freed from desire, became an eminent abbot with many disciples and died at a very advanced age, while the husband became rich with the blackmail money. ${ }^{41}$ Here, the consequence is not all bad and the moral stance is somewhat ambivalent. The lustful monk is punished yet given another opportunity. Probably for this reason, it was not easy to adapt as a Ming gong'an story, which must always express a black or white moral stance.

There are also collections whose contents purport to be Song and Yuan, but were compiled (or rather written or re-written, perhaps inspired by fragments of older materials) by Ming scholars. ${ }^{42}$ These include the Qingping shantang huaben 清平山堂話本 (hereafter the Qingping shantang) by Hong Bian 洪梗 and the Sanyan 三言, three short story collections by Feng Menglong. ${ }^{43}$ These collections contain only one "criminal monk" story, the Jiantie heshang 簡貼和向, which appears in substantially the same form in both the Qingping shantang and the Sanyan. ${ }^{44}$ This story is also a popular theme in Song and Yuan plays. ${ }^{45}$ It follows the outline of the above-mentioned "Wife of Wang Wugong" in Yijianzhi, but the details are all changed. The story tells of a monk who desires Mr. Huangfu's 皇甫 wife and has someone deliver her a love-letter so as to deceive Huangfu into thinking that she has been having an affair. His ploy succeeds and Huangfu divorces her. The monk returns to lay life and marries her. Later he tells her the story; she is shocked and angered. She and her former husband bring charges against the monk before the magistrate. This was a popular motif in the gong'an stories, as mentioned above.

\footnotetext{
41) Ibid., juan 1: binji 8-10.

42) For the dating of these stories, see also Hanan, The Chinese Short Story.

43) Of course, one must be extremely careful to use the Sanyan as a source for earlier material, as the Sanyan are post-1620 works, later than the gong'an collections. In fact, some Sanyan stories obviously derive from gong'an stories.

44) Hong Pian, Qingping shantang huaben (Beijing: Wenxue guji kanjing she, 1955), 1:3-12. The Yushi mingyan 喻世名言 is also known as the Gujin xiaoshuo. Feng Menglong 馮夢龍, Gujin xiaoshuo 古今小說 (Beijing: Renmin wenxue chubanshe, 1984), 543-56. It is also included in the early sixteenth-century bibliography of Song and Yuan literature, the Baowentang mulu 寶文堂目錄.

45) Hanan, The Chinese Short Story, 185. Hanan judges it to be a development of the Yijian$z h i$ item through oral fiction or drama.
} 
In sum, the "criminal or rapist monk" theme was not entirely an invention of the authors of late Ming gong'an stories. It existed already in Song and Yuan times, in various genres: biji anecdotes, legal case collections, classical tales, vernacular novellas (huaben), dramas, and plays. However, it was not until the late sixteenth century that this theme gained much popularity. Writers then tended to seize on every available earlier tale that fit the pattern. Of course, it is not impossible that stories of this kind circulated more widely in pre-Ming times and were subsequently lost. However, the fact that we can identify only a handful of such stories suggests that the "criminal monk" as a well-established literary topos is a distinctively late Ming phenomenon.

Another crucial question concerns the purpose of these gong'an stories. Many scholars argue that this was practical. The eminent historian of Chinese literature Sun Kaidi 孫楷第 claimed that late Ming courtroom tales were designed to teach judicial writing, citing in evidence the fact that many of them include complaints and verdicts. ${ }^{46}$ This view has been influential among Chinese scholars. ${ }^{47}$ I find this claim unconvincing. Take for example the two collections Lianming gong'an and Zhusi gong'an published by Yu Xiangdou. These were among the earliest collections of gong'an stories. Yu, as editor-cum-author, had almost no precedent to follow. He selected (and edited) stories from various sources, including folk stories and legal textbooks. In fact, we can infer from the fact that judicial plaints were randomly included that these stories were not intended as legal training materials.

Furthermore, the plaints and verdicts are written up in a style completely inappropriate to a legal context. Take for example a story in Lianming gong'an, in which a monk seduces and abducts a woman on her way to her natal family home after a fight with her husband. The woman's disappearance leads to a lawsuit between her natal family and her husband, who is accused of murdering his wife. When the truth is revealed, the magistrate writes the following verdict:

\footnotetext{
46) Sun Kaidi, 孫楷第, Riben Dongjing suojian zhongguo xiaoshuo shumu 日本東京所見中國 小說書目 (Shanghai: Shangza chubanshe, 1953), 141.

47) For example, Meng Liye defines this literature as "judicial case-study fiction" (panliti xiaoshuo 判例體小說). Meng Liye 孟犁野, Zhongguo gong'an xiaoshuo yishu fazhanshi 中國 公案小說藝術發展史 (Beijing: Jingguan jiaoyu chubanshe, 1996).
} 
As the investigation has revealed, the monk Shuiyue has not eliminated his old habits and still seeks to satisfy desire. [He] met a woman and abducted her in the dark. The monastery is no Zhiyuan [a famous monastery where the Buddha used to preach], yet it has the delicate flower [a woman]; the cell is no Ruizhu palace [where the fairies resides], yet it hides the bodhisattva [a woman]. [A monk] who has drowned in the sea of desire cannot ascend to the Tușita heaven; being obsessed with the sea of love, [he] will fall eternally into Fengdu [a Daoist hell]. [He] should be sentenced to exile for two years and forcibly return to the laity. He Yiniang [the woman in the case] has eloped. This is unlike [Zhuo] Wenjun [eloping with Sima Xiangru]. This would make [Zhong] Wuyan feel ashamed. [She] makes cloud and rain [makes love] in the sacred room, contaminating the immaculate Buddha's head... [She] should be sentenced to be officially sold (into slavery), as a warning to other womenfolk... ${ }^{48}$

審得僧水月, 未除結習, 求構欲緣。紅粉陡逢, 黑地拐去。寺非賽祗圓, 坐擁 花嬌; 倉豈芯珠宮, 深藏菩薩。沉淪欲海, 難登兒率之天; 迷戀愛河, 永墮酆 都之地。合徒二年, 發遣歸俗。賀宜娘私奔, 難比文君野合。深嶃無艷, 仙房 通雲雨, 點污無垢佛頭 ... 合行官賣, 用儆女流 ...

The verdict is full of literary references and expressions of personal feeling, with strongly moralistic overtones. The description of facts is of secondary importance. For example, the author compares the adulterous woman with two historical or legendary figures: Zhuo Wenjun 卓文君 and Zhong Wuyan 鐘無豐. The former was a girl from a rich family, who eloped with the poor but talented Sima Xiangru 司馬相如. The latter volunteered to serve in King Xuan of Qi's 齊宣王 harem so that she could have a good influence on him. Both are positive examples of women running off with men. The author's view is complex and not entirely orthodox: eloping is not always bad. But here it is a crime because it involves a monk and someone's wife, and because sex is the only attraction.

The application of law is wrong as well. According to the Ming law, this case would belong to the category of "abduction and adultery" (diaojian 了奸), the punishment for which was a hundred strokes of the cane for both men and women. The husband then would have the right to sell his adulterous wife (but not to her lover). ${ }^{49}$ If one guilty party was a Buddhist or Daoist cleric, he or she should receive a harsher

48) Lianming gong'an in Guben xiaoshuo congkan, juan xia:1248.

49) Daming lü jijie fuli 大明律集解附例 (Taipei: Xuesheng shuju, 1970), 25:1. 
punishment of seventy strokes plus exile for a year and half. ${ }^{50}$ But the author of this tale clearly did not worry much about these technical details of legal practice; and the same is true of gong'an stories in general.

This style of writing up judicial verdicts follows literary rather than legal practice. Take, for example, the above-mentioned Yuan fiction anthology Zuiweng tanlu. Its author divides oral vernacular fiction (or xiaoshuo 小說) into eight classes, one of which is named gong'an (the same two characters as in the Ming counterpart). ${ }^{51}$ There are then two further subdivisions of the gong'an class: siqing 私情, about elopement, and huapan 花制, largely cases involving prostitutes and courtesans. The huapan subdivision contains fourteen short stories, each of which ends with a "flowery verdict" (huapan). The verdict is usually a poem. Obviously, the reader is not supposed to read this as a record of real judicial practice; it is merely a playful literary conceit. The monk Liaoran's story falls under this huapan subdivision. Here is its "flowery verdict," in the form of a song lyric ( $c i$ 詞) to the tune Tasha xing 踏莎行:

This bald slave is sloppy in his religious cultivation. He follows a vegetarian diet on the top of a snow mountain. Seduced by woman in the jade tower but embarrassed by his broken clothes, he hurt her with his malicious hand, breaking her flower-like face into pieces. Where is the doctrine of śünya and rūpa? To relieve the suffering of love, he has tattooed the "way" on his arm. Now, he has paid the debt of love. ${ }^{52}$ 这个秃奴, 修行忒繁, 雲山顶上持斋戎。一从迷恋玉楼人, 敦衣百结浑无奈。 毒手伤人, 花容粉碎, 空空色色今何在? 臂间刺道苦相思, 这回还了相思债。

This verdict is copied, almost word for word, in the same story in Lianming gong'an, although the preceding narrative has more twists. Clearly, the author of Lianming gong'an (probably Yu Xiangdou himself) was not serious about getting the legal aspects of the case right, as he must have known that Zuiweng tanlu was a fictional anthology.

Compare this to a real adultery and murder case recorded in a case compilation from the Qianlong reign (1736-1796) — the Ming legal records furnish no cases involving lecherous monks, but we can assume that such cases would have been written up in a similar fashion: Qing legal practice followed Ming practice closely. The case goes, in brief: a

\footnotetext{
50) Ibid., 25:10-11.

51) Zuiweng tanlu, juan 1: jiaji 6-10.

52) Ibid., juan 2: gengji 7-8.
} 
certain monk living off of ritual services outside the monastery (yingfuseng 應赴僧) Hengyi had an affair with Mme. Gu née Fei, the wife of the actor Gu Hongjin. Hongjin's nephew Gu Achang spread a rumor about this affair, whereupon Hengyi instigated Hongjin to kill Achang. Hongjin, with the assistance of his uncle Wu Shouzhong, drowned Achang. The verdict runs as follow:

Stay-at-home monk Hengyi should be forcibly returned to the laity. According to the law of murder, the chief plotter is to be beheaded. [I] hereby suggest beheading subject to revision after the autumn assizes. Wu Zhouzhong is an accomplice. According to the law, [I] hereby suggest strangulation subject to revision after the autumn assizes. They should also be tattooed [on the face] and cannot be pardoned. Gu Hongjin should be sentenced to a hundred strokes of the cane plus exile to a distance of two thousand li (about $500 \mathrm{~km}$ ), according to the law on qiqing [mourning rank] uncle man-slaughtering nephew. Woman Fei should be sentenced to ninety strokes of the cane according to the law against encouraging adultery.

應赴僧恒一, 應勒令還俗。依謀殺人造意者斬律, 應擬斬監候, 秋後處。吳守 忠合依從而加功者絞律, 應擬絞監候, 秋後處。俱照例刺字, 不應援赦。顧宏 錦合依期親叔叔故殺侄律, 杖一百, 流二千里。費氏合依縱容通姦律杖九十。53

This judicial verdict differs greatly from the "verdicts" in both our gong'an story and Zuiweng tanlu. It is written in dry and formal bureaucratic language. It spells out crimes and punishments in a matter-of-fact way. Accuracy in the application of the law is of the essence; no personal feeling is expressed. It is clear that the gong'an stories were not intended as training materials for legal practitioners. In any case, there were textbooks devoted to the writing of judicial documents in Ming and Qing times.

The main function of gong'an stories was, in my opinion, to entertain. A large number are about murder or sex crimes-presumably the two most entertaining topics in legal fiction-or sometimes both. ${ }^{54}$ Many of them contain detailed and explicit descriptions of sex and violence, in relatively vulgar language. The following is typical:

\footnotetext{
53) Neige hanwen tiben zhuanti dang'an: xingke hunyinlei tiyao 內閣漢文題本專題檔案: 刑科 婚姻類提要 (digital edition in Academia Sinica Hanji database), 2-7:1.

54) For example, Lianming gong'an has 18 cases of murder or sex crimes out of 59 cases and Zhusigong'an has 31 out of 103 cases.
} 
... The woman thought the bald deity was coming to give her offspring, so approached [him] naked. The monk climbed onto the bed lightly, holding the woman. The jade stalk [penis], erect and hard, came in at once and retreated slowly. The woman's body became soft and pliant. [They] fought the battle for a long time. The sperm spilled on the mattress. When the cloud and rain [sex] was over, the woman went to sleep, and the monk sneaked out. ${ }^{55}$

... 婦人已謂秃頭仙送子來也, 逐祖身仰上。和佮輕輕舉步就牀, 將婦人摟抱, 玉茥雄健, 一槍直入, 緩䋧抽撤。婦人遍體酥麻。戰而且久, 精溢於席。雲雨 已訖, 婦人睡去, 和佮輕輕潛出。

This comes from a story in Xiangxing gong'an - one of the most popular stories, recycled, with variations, many times. ${ }^{56}$ It is about women who go to the monastery to pray for offspring and end up being raped by monks. The monks invite the women into the monastery overnight to wait for a certain "bald deity," who will give them babies. Many women fall into the trap. The story is clearly written from a male perspective. The description of sex is florid but tasteless. We sense little sympathy for the women victims. Instead, there is a mocking and contemptuous tone-the women are portrayed as mere sex objects. In conclusion, it seems that the focus on rapist monks in gong'an literature was a new development of the late Ming, unrelated to contemporary legal writing. How can we explain this?

\section{Monks and Sex Crimes in Late Imperial Times}

The popularity of "bad monk" stories in the sixteenth century is often cited as evidence for a "vulgarization of Buddhism" (fojiao shisu hua 佛教世俗化) in late imperial China—a popular view especially among Chinese (including Taiwanese) scholars. ${ }^{57}$ "Vulgarization" here might

\footnotetext{
55) Xiangxing gong'an in Guben xiaoshuo congkan, 3:1145-53.

56) A similar story can be found in Lianming gong'an as well as the short-story collections Sengni niehan 僧尼蒘海 and Feng Menglong's novella collections Xingshi hengyan 醒世 恒言: Huang San, Jean Blasse (transl.), Moines et nonnes dans l'océan des péchés 僧尼萑海 (Arles: Philippe Picquier, 1992), 118-24; Xingshi hengyan (Hong Kong: Zhonghua shuju, 1958), 39:838-51; Lianming gong'an in Guben xiaoshuo congkan, juan shang:1092-1101.

57) The Chinese phrase fojiao shisu hua is sometimes translated as "secularisation of Buddhism". But this is paradoxical. This phrase, in fact, is used to mean that Buddhism went down in the world-deteriorating from an elite religion to a popular or vulgar practice; it implies the loss of "sacredness."
} 
refer to a decline in clerical morality; the claim, then, would be that lecherous and murderous monks became more common in fiction because they were more common in reality. ${ }^{58}$ This claim is prima facie implausible. Of course, literature is always conditioned by its social context. But it is a crude fallacy to treat literature as a simple mirror of social reality. Literature reflects the motivations of its authors, the taste of its readers, the beliefs and perceptions of contemporaries, and the class structure of the wider society, and no doubt other things too. But to prove the point, let us look at the legal literature concerning monks and sex crimes.

Sex crimes, known as fanjian 犯姦, covered both adultery and rape. The Ming law stipulated that any Buddhist monk or Daoist priest committing a sex crime should be subject to a sentence two degrees harsher than that meted out to non-clerics. ${ }^{59}$ Treating the clergy as a special category in sex crimes was a Ming innovation, inherited, like most such innovations, by the Qing authorities. Nevertheless, it would be wrong to read it as evidence that clerics were more likely to commit sex crimes in the Ming and Qing than in earlier periods. The fact is that there was more legislation governing clerical behavior in general in the Ming. In order to restore Chinese values and restructure Chinese society after nearly a hundred years of Mongol rule, the Ming founder, Zhu Yuanzhang 朱元璋 (1328-1398), attempted to construct an all-encompassing state ideology based on Confucianism. ${ }^{60}$ This included strict control of monasteries and the clergy. Monks could not travel freely or associate with government officials. ${ }^{61}$ The social mixing of monks with the gentry, though common in the late sixteenth century, was discouraged. ${ }^{62}$ The general purpose of Zhu Yuanzhang's religious policies was to detach the

\footnotetext{
58) For example, Lin Cuiyao, "Jian, xie, yin, dao"; Tiao Haitong, "Mingdai shiqing xiaoshuo Zhong de sengni xingxiang yanjiu” 明代世情小說中的僧尼形象研究 (Ph.D. diss., Zhongyang minzu daxue, 2012); Wang Shaoxing, "Mingqing sengni shehui xingxiang de wenhua toushi" 明清僧尼社會形象的文化透視, Shehui kexue jikan 3 (2007): 172-78.

59) Daming lüjijie fuli, 25:10-11.

60) Edward L. Farmer, Zhu Yuanzhang and Early Ming Legislation: The Reordering of Chinese Society Following the Era of Mongol Rule (Leiden: Brill, 1995), 4-17.

61) Wu Jiang, Enlightenment in Dispute: The Reinvention of Chan Buddhism in SeventeenthCentury China (Oxford: Oxford Univ. Press, 2008), 22.

62) Timothy Brook, Praying for Power: Buddhism and the Formation of Gentry Society in Late Ming China (Cambridge, Mass.: Harvard Univ. Press, 1993), 91-95.
} 
Buddhist clergy from society. ${ }^{63}$ It is thus not surprising to find the clergy listed as a separate group in law. As well as sex crimes, the clergy were also treated as a distinct category in laws governing marriage and rites. ${ }^{64}$

Although the law against sex crimes might have helped create a generally negative image of clerics, there is no evidence that clerics were accused of or prosecuted for sex crimes more frequently than other social groups. No case compilation survives from the late Ming, but many magistrates' handbooks from this period have been preserved. Sex crimes were a much-discussed topic in these handbooks and it was commonly agreed that false accusation was particularly easy in cases of adultery and rape. ${ }^{65}$ Buddhist monks are not mentioned either as frequent perpetrators or as scapegoats. ${ }^{66}$

Many Qing case compilations survive. Rather than attempt a survey of them all, I have consulted five containing a selection of the most classic and controversial cases of the period. These are representative enough to serve our analysis. ${ }^{67}$ Cases involving the clergy form only a small fraction of the total (twenty-three cases in all five compilations, including those in which clerics are victims). ${ }^{68}$ Nearly half these cases concern monastic violence, most commonly involving monks assaulting novices and disciples; ${ }^{69}$ others concern violence precipitated by financial quibbles between monks and non-clergy. ${ }^{70}$ The case compilations

63) Ibid., 22.

64) Daming lü jïie fuli, 6:32-33; 12:19-20.

65) Fuhui quanshu 福惠全書, 19:23-25, in Guanzhenshu jicheng 官筬書集成, vol. 2 (Hefei: Huangshan shushe, 1997), 432-34; Lizheng zhaiyao 莅政摘要, xia:20-22 in Guanzhenshu jicheng, vol. 4, 648-49; Ban'an yaolüe 辦案要略, 10 in Guanzhenshu jicheng, vol. 6; Mulingshu 牧令書, 19:63-65 in Guanzhenshu jicheng, vol. 7, 451-52.

66) This is based on a survey of the magistrates' handbooks collected in the Guanzhenshu jicheng.

67) They are: Ma Shilin 馬士璘, Cheng'an suojian ji 成案所見集 (1793, one case involving the clergy); Yaerhashan 雅爾哈善, Cheng'an huibian 成案彙編 (1746, five cases involving the clergy), Wang Jinzhi 汪進之, Shuotie bianli xinbian 說帖辨例新编 (1836, six cases involving the clergy); Zhu Meichen 朱梅臣, Bo'an huibian 駁案彙編 (1884, seven cases involving the clergy), and Xingke hunyinlei tiyao (four cases involving the clergy).

68) To give a rough idea, Bo'an huibian contains 380 cases in all. Shuotian bianlixingbian has forty-eight juan and the twentieth juan alone contains 27 cases. Cheng'an huibian contains 2691 cases. We can infer that the total number of the cases must be well over four thousand. 69) Bo'an huibian, 19:25-26; 40-42; 43-45; 46-49; 34:6 (five out of seven, the last one concerns a monk beating his own brother to death); Cheng'an huibian, 20:55; 56; 57 (three out of five); Cheng'an suojian ji, 22:47-49 (one out of one); Shuotie bianlixinbian, 32:21-27 (one out of six). 70) Xingke hunyinlei tiyao, 26:3; Shuotie bianli xinbian, 31:73. 
reveal that clerics were sometimes victims of such petty crimes as stealing, perpetrated either by other clerics or by non-clerics. ${ }^{71}$

Seven out of these twenty-three cases concern monks convicted of sex crimes (adultery and rape). Most of the seven involve adultery (leading to murder or suicide $)^{72}$ and only one involves rape (leading to murder). ${ }^{73}$ Although these seven cases make up a fair proportion of cases involving monks (just under a third), they represent only a tiny fraction of sex crimes in general.

Perhaps here we should also consider the population of Buddhist clerics. Vincent Goossaert, in his detailed study of the 1736-1739 census of the clerical population, claims that the proportion of Buddhist monks was very low: under 300,000 , constituting less than 0.2 percent of the whole population. However, as Goossaert also points out, this figure was probably a huge underestimate, as many who were identified as "monks" in local society were in fact not registered clerics, and monastic novices were not included in the census. ${ }^{74}$ The number of cases involving monks in our five compilations is about $0.6 \%$ of the total. ${ }^{75}$ This may be proportionate to number of monks in the population. It appears, in short, that monks were not commonly implicated in crime in the Qing period, and the same is probably true of the late Ming. The number of cases involving sex crimes is too small to allow us to draw any general conclusions.

As Ming and Qing magistrates often pointed out, false accusations were common in adultery cases. Did the image of the "lecherous monk" in literature make the clergy more vulnerable to slander than the nonclergy? In his monograph on murder and adultery in late imperial China, M.J. Meijer claims that "it is a well-known fact that Buddhist monks especially were not in the government's grace, as they were suspected of sexual debauchery and deceit of the population." ${ }^{76}$ I am skeptical of this

\footnotetext{
71) Bo'an huibian, 2:1-4 (the monk was the victim of theft); 7:1-4 (the monks were robbed by a non-clerical criminal). Cheng'an huibian, 20:57 (a novice robbed and murdered his teacher); 19:108 (a couple murdered a nun and pretended her dead body was that of their daughter in order to break the latter's engagement).

72) Shuotie bianli xinbian, 30:3-6; 42:39; 42:40; Xingke hunyinlei tiyao, 7:1; 12:10; 21:8.

73) Cheng'an huibian, 19:108.

74) Vincent Goossaert, "Counting the Monks: The 1736-1739 Census of the Chinese Clergy," Late Imperial China 21:2 (2000): 40-85.

75) This is assuming that the total number of the cases is four thousand.

76) M.J. Meijer, Murder and Adultery in Late imperial China: A Study of Law and Morality (Leiden: Brill, 1991), 32.
} 
statement since we do not have enough judicial evidence to prove it. Nevertheless, the literary image of the "lecherous monk" may sometimes have been invoked by non-clerical litigants to their advantage. Often, when a monk was involved in a local property dispute, his opponent would accuse the monk of breaking monastic rules by visiting prostitutes, gambling, taking drugs, or swindling 不守清規, 嫖賭吸煙欺. ${ }^{77}$ These were stock phrases, conveying only that the monk concerned had a bad character. The logic was: if he is morally bad, he must have behaved wrongly in the property dispute. The actual case had nothing to do with a sex crime, nor did the official bother to confirm these accusations of sexual misconduct.

Consulting the archives of Ba county (modern Chongqing), Karasawa Yasuhiko found a few cases in which sexual misconduct was used to frame Buddhist clerics during the Daoguang reign (1821-1850). ${ }^{78}$ Such framing was probably not restricted to the nineteenth-century Ba region, and these cases of sexual misconduct are just some among many other cases involving monks recorded in the Ba archives, the majority involving financial disputes. No stereotypical association of monks with adultery or rape is discernible in Qing legal practice. That said, clerics must sometimes have been falsely accused of sexual misconduct. A late Ming magistrates' handbook, the Zheyu xinyu 折獄新語, a collection of cases and verdicts by Li Qing 李清 (1591-1673) based on cases he had judged while a magistrate in Ningbo, contains the following example. A certain woman, Gao, accused a Buddhist nun named Wuzhen and a monk named Liaoyuan of having an adulterous relationship. She claimed to have seen the latter giving the former a lotus as a love present. In fact, Liaoyuan had given the lotus to Wuzhen for her to place in front of the altar. Ms. Gao wanted to frame the nun because the latter had refused to lend her some rice. ${ }^{79}$ Clearly, Gao was convinced that she could achieve her end by fabricating a story about a monk-nun romantic liaison. Stories of this kind must have appeared plausible to contemporary eyes. They fit a certain social perception of the clergy. As Karasawa Yasuhiko writes, "the stories in plaints had to be culturally acceptable so

77) Nanbu County Archive: 6o.638.4. My thanks to Dr. Tristan Brown for pointing out this to me.

78) Karasawa Yasuhiko, "Between Oral and Written cultures."

79) Zheyu xinyu 折獄新語 (Beijing: Zhongguo shehui kexue chubanshe, 2005), 4:635. 
that every participant in the litigation process, including the magistrate, would be convinced that the plaints were plausible." 80

Among the cases that I have looked at in the five Qing case compilations, there are at least two in which accusations of lechery could have been fabricated to the detriment of a cleric. The Xingke hunyinlei tiyao 刑科婚姻類提要 records a 1735 case about a monk named Zhaoqing who was killed during a fight with a builder over the latter's wage for his work in a monastery. The builder explained the reason he had beaten the monk so hard was because the latter tried to seduce his wife when she went to ask for her husband's wage. ${ }^{81}$ We cannot know whether this really happened; it may well have been fabricated by the builder in order to obtain clemency. The Cheng'an huibian includes a 1729 case in which a novice monk murdered and robbed his teacher in collusion with a mendicant monk who had come to stay with them in their monastery. The novice claimed that his motive was revenge rather than avarice, as his teacher had once tried to seduce his mother when she came to visit. ${ }^{82}$ If (as seems likely) this was a bid for clemency on the part of the novice, it was successful: he managed to get off with a lighter sentence than he would normally have received. Under Qing law, the monastic teacher-disciple relationship was analogous to kinship: assault or murder of a teacher incurred more severe punishment than assault or murder of a person of the same station. The judge's verdict took the disciple's testimony into consideration, arguing that the teacher-disciple relationship had in this case been undermined by the perverted, sinful act of the teacher-monk. ${ }^{83}$

\section{Anti-Buddhist Sentiments}

If the prevalence of wicked monks in Ming gong'an stories does not reflect any real decline in clerical behavior in this period, might it nonetheless reflect a decline in the public reputation of monks? Should it, in

\footnotetext{
80) Karasawa Yasuhiko, "Between Oral and Written cultures," 77.

81) Xingke hunyinlei tiyao, 2-26:3.

82) Cheng'an huibian, 20:57.

83) M.J. Meijer discusses a similar story in 1792: the novice killed his teacher because the latter had an illicit love affair with his mother, and the novice received a mitigated sentence. See Meijer, Murder and Adultery in Late imperial China, 108.
} 
other words, be interpreted as evidence of anti-Buddhist sentiment in late imperial Chinese society? ${ }^{84}$ This hypothesis might be based on assumptions drawn from the history of Europe, which saw many outbursts of anticlerical sentiment in this period, particularly in the decades surrounding the French Revolution of 1789 . Often, these took a pornographic form, inviting comparison with the equally pornographic depiction of monks in Chinese courtroom tales. Here, for instance, is Robert Darnton on the novel Thérèse Philosophe, an underground bestseller in pre-revolutionary France:

He (Father Dirrag) prescribed spiritual exercises based on the principle of freeing the spirit by mortifying the flesh. Flagellation was his favorite technique. He used it to purge the body of impurities and lift the soul into an ecstatic state, which could even lead to sainthood. ${ }^{85}$

Here, seduction by a cleric is presented as a blasphemous parody of Christian spiritual practice. The lecherous Dirrag instructs women in libertinage in the same way he might instruct them in the Christian faith. Religion, by implication, is a form of seduction. Sacrilege and sex go hand-in-hand.

Were late Ming gong'an stories involving lecherous and rapist monks inspired by a similar kind of anti-religious sentiment among the "enlightened"? The inference is especially tempting because Ming China and early modern Europe exhibit some strikingly similar social conditions, including rapid urbanization, increasing literacy, the emergence of a "merchant-gentry" class, new printing techniques, and a concomitant reduction in the price of books. Such similarities might lead one to postulate a secularizing trend in late imperial China, of which these stories are an expression.

However, the hypothesis does not stand up to scrutiny. First and foremost, there was no secularization of thought or practice in late Ming Chinese society. On the contrary, this period is often regarded as one of

\footnotetext{
84) For example, Oki Yasushi 大木康 claims that there was an anti-Buddhist trend, originating at court, in the late Ming, especially during the Jiajing period. See Oki Yasushi, “Mingmo 'e’seng xiaoshuo' chutan” 明末 “惡僧小說” 初探 in Zhongzheng hanxue yanjiu 中正 漢學研究 2 (2012): 183-212.

85) Robert Darnton, The Forbidden Best-Sellers of Pre-Revolutionary France (New York: HarperCollins, 1996), 92-93.
} 
Buddhist revival. During the reign of the pro-Buddhist Wanli Emperor (1573-1620), Buddhism experienced some kind of renewal. Several scholastic Buddhist traditions underwent doctrinal development. ${ }^{86}$ There was an upsurge in temple building and a growth of imperial patronage, thanks both to the Emperor and his mother, Empress Dowager Xiaoding. The mid-late sixteenth century also witnessed the formation of a close relationship between Confucian scholars and scholarly monks. Many of the educated elite cultivated a Buddhist persona; correspondence between scholars and monks was common; gentry patronage of Buddhist monasteries (to be distinguished from village-based fund-raising temple associations) flourished. ${ }^{87}$ The new philosophical movements of the day were heavily influenced by Wang Yangming 王陽明 (1472-1529), who blended Buddhist thought into his interpretation of Confucianism. A secularized elite, if we can use such a term at all, did not appear until the late nineteenth and early twentieth century, with the first influx of Western ideas.

In spite of the prevalence of Buddhist beliefs and ritual practices, Buddhist doctrine occupied nothing like the monopolistic position of Christian doctrine in pre-Revolutionary Europe. Confucianism or $r u$, rather than Buddhism, was the main source of social morality. The Buddhist sangha was never an authority on a par with the Catholic Church in pre-Revolutionary France. It was always subordinate to the political authorities. In fact, it is not even entirely accurate to speak of a "Buddhist sangha" in late imperial China. Monasteries and temples were independent of each other and did not form an institutional and administrative entity. 88 They were not organized hierarchically, although they differed significantly in terms of wealth and level of patronage. And although monks considered themselves as belonging to the sangha, this sangha was more a spiritual than an institutional entity. We cannot regard the gong'an stories as an attack on a powerful and resented social estate.

\footnotetext{
86) $\mathrm{Wu}$, Enlightenment in Dispute, 26-28.

87) Brook, Praying for Power, 159-84.

88) The short-lived conglin 叢林 system of the seventeenth century, which distinguished public monasteries where the abbot was elected from among worthy candidates from ordinary cloisters, never properly worked. Wu, Enlightenment in Dispute, 29-52.
} 
Polemics against Tibetan monks, known as xiseng 西僧 or xifan seng 西番僧, were somewhat more politically oriented than those against Chinese Buddhist monks. Tibetan monks enjoyed some privilege in the Mongol Yuan (1279-1368) period, which, no doubt, stirred up resentment among the Han population. The Manchu Qing rulers were also noted for their lavish patronage of Tibetan Buddhism. Tibetan tantric practices (involving techniques using sexual imagery) served as a convenient source of insinuation: there are many stories about Tibetan monks possessing extraordinary sexual capacity or selling aphrodisiac medicines. The criticism of Ming writers often has two targets: the misbehavior of Tibetan monks on the one hand, and their pernicious influence on the emperors on the other hand. In fact, the collapse of the Yuan was often attributed to such claims. ${ }^{89}$

But the Ming polemic against Tibetan monks was still very different in character and motivation to French eighteenth-century anticlerical literature. The Tibetan clergy was widely perceived as "foreign" and indeed not even Buddhist. It therefore figured ambiguously in the Chinese imagination: its practices that used sexual imagery fed into the existing anticlerical theme of sexual misconduct, yet its exoticism aroused hostility and mistrust as well as fascination. Anticlericalism here was another expression of xenophobia. If one wants to draw a European parallel, one might find it in the hostility of early modern English Protestants to the Jesuits, who were similarly regarded as combining heterodoxy, foreignness, and sexual deviancy.

Let us go back to the literary topoi in the eighteenth-century French and sixteenth-century Chinese literature. Pre-revolutionary French anticlerical novels are generally cynical in their attitude to religion. The priests do not have religious faith themselves; they openly mock Christian doctrine; and this attitude is shared by the author. In other words, the author and his characters are equally blasphemers. This cynical or sacrilegious attitude is lacking in Ming stories. Monks are often mocked for their shaved heads, a marker of their clerical identity, probably because the Chinese word for "shaved" (guang 光) is the same as the word for "naked," and "head" could easily be twisted to mean the "little head"

89) Isabelle Charleux, "Les « lamas » vus de Chine: fascination et répulsion," Extrême-Orient, Extrême-Occident 24 (2002): 133-51. 
(penis), but this is hardly sacrilege. Buddhist teaching is never the target of satire, nor are Buddhist rituals travestied, as Christian rituals are in Thérèse Philosophe. Ming authors adopt a respectful attitude towards Buddhism and a puritanical attitude towards sex. This attitude is particularly prominent in our gong'an stories, in which fornicators always end badly.

Pre-revolutionary French forbidden books not only mock clerics, but also noblemen and high officials. Clerics are classed among the powerful and illustrious. Sex is often used as a political metaphor. For example, in Anecdotes Sur Mme La Contesse Du Barry, ${ }^{90}$ Madame Du Barry, a former prostitute and later countess, successfully climbs the social ladder by strategically sleeping around in high society, including with bishops and high officials. She observes that the higher a person's social station, the less sexually potent he or she is. She herself can only find satisfaction in the servants' quarter. This is clearly intended as a political parody on the effeteness of the powerful. Eighteenth-century "libertine writing" was often closely connected with political subversion. ${ }^{91}$ It was branded together with anti-regime propaganda under the heading of "philosophical books." The Church was widely regarded as a spiritual prop of the monarchy; attacks on one often mingled with attacks on the other.

The gong'an collections were neither political parodies, nor forbidden literature. Monks appear not as allies of the powerful, but as members of a despised social estate. Indeed, they are little more than criminal lowlifes, equivalent in status to other stereotypical perpetrators of sex crimes such as butchers, yamen runners, and servants. Neither are they presented as bearers of a spiritual vocation. Buddhism as a religion is not mentioned. Finally, the authors of gong'an stories maintain a conventionally deferential attitude to the authorities. Lascivious monks and careless women are both bad and punishable, one by law and the other by fate. "Libertinage" as a sexual and political value is entirely absent from the gong'an stories.

In sum, we cannot explain the frequent appearance of clerical rapists and seducers in Ming courtroom tales either as a reflection of actual

90) Darnton, The Forbidden Best-sellers of Pre-Revolutionary France, 137-66.

91) John Phillips, "Old Wine in New Bottles? Literary Pornography in Twentieth-Century France," Perspectives on Modern European Pornography, 1800-2000, ed. Lisa Z. Sigel (New Brunswick: Rutgers Univ. Press, 2005), 125-45. 
clerical behavior or as an expression of anti-Buddhist sentiment. How can we explain it, then?

\section{Literary Culture in the Ming}

One possibility worth exploring is that the "lecherous monk" theme was a convention of a certain type of recreational literature. Monks in general were not despised in the Ming: there are many positive as well as negative portrayals of monks in contemporary biji anecdotes. We cannot infer what Ming dynasty readers really thought of monks from the way they are portrayed in gong'an stories, any more than we can infer what modern film goers really think of the police from their often-bumbling appearance in detective films.

Sixteenth-century China underwent drastic social changes. Towns and commerce developed rapidly, disrupting existing social structures. A new "commercial elite" emerged. Urbanization and commercialization also led to an increase in literacy, since it was difficult to thrive in towns if completely illiterate. The rise in literacy, particularly moderate literacy, created a demand for more books, especially popular, recreational books. Commercial printing houses sprang up and competed with each other. ${ }^{92}$ Increasing specialization reduced the cost of cutting woodblocks, causing book prices to fall. ${ }^{93}$ All this resulted in an expansion of entertainment literature. The gong'an collections, together with many other forms of fiction, were precisely the outcome of this new book culture.

Gong'an stories were not masterworks of literature. As they were produced anonymously, we have little information about the authors. But judging by their style, they were unlikely to have been prominent literati like Feng Menglong. They must have had some education, however, or they would not have been able to write classical Chinese at all. As mentioned above, some authors write floridly, with many literary and historical references, which would have required a certain educational

92) For commercial publishing houses in the Ming, see Chen Dakang 陳大康, Mingdai xiaoshuo shi 明代小說史 (Shanghai: Shanghai wenyi chubanshe, 2000), 170-75.

93) Robert Hegel, Reading Illustrated Fiction in Late Imperial China (Stanford: Stanford Univ. Press, 1999), 23-127. 
level. Writing stories for commercial publishers might have been their "part-time" job, or even hobby. Some writers might have been professionals employed by commercial publishers to write this kind of literature. ${ }^{94}$ For example, Patrick Hanan, in his study of the three existing versions of Judge Bao's Hundred Cases (Baijia gong'an), judges its authors to have been professionals working for commercial publishers. ${ }^{95}$

What about the readers? Unfortunately, we lack publishers' lists, a tool often used in the study of the history of the book in Europe, so it is difficult to work out precisely the quantity and character of a book's readers. ${ }^{96}$ Books on the whole were expensive in pre-modern China and would have been beyond the means of an impoverished household. But, what is clear is that these gong'an collections, unlike some beautifully printed and bound books, were not luxury goods. Many readers were likely to have been urban dwellers such as shop clerks, moderately educated and not very rich.

However, we cannot assume that gong'an stories were not also read by the elite. The fact is that there was no clear-cut boundary between elite and non-elite reading material; stories that appealed to the nonelite population might also appeal to the members of elite. Evidence for this comes from the Ertan 耳談, a late Ming biji collection-a kind of literature that was written by literati and read by highly educated people. It was published in 1598, roughly the same time as the emergence of the gong'an genre. Its author, Wang Tonggui 王同軌 (d.u.), was a famous writer and former magistrate. Later, in the Qing, it was included in the Siku quanshu. The Ertan contains several stories about bad, even criminal monks, which are identical in plot to those in the gong'an stories. One story goes as follows: a student from the $\mathrm{Wu}$ region frequents a monastery and befriends a monk there. One day, the student revisits the monastery, but the monk happens to be out. He accidently bumps into a woman and realizes that the monk has been keeping women in the monastery. When the monk returns and finds his secret exposed, he tries to kill the student. The student pleads to be allowed to hang himself instead. He also requests some wine to drink. The monk sends for wine and drinks together with the student, who then kills the monk

94) Chen Dakang, Mingdai xiaoshuo shi, 402.

95) Hanan, "Judge Bao's Hundred Cases Reconstructed," 301-23.

96) See, for example, Darnton, The Forbidden Best-Sellers of Pre-Revolutionary France. 
with the wine jar when an opportunity arises. It turns out that five or six women are being kept in the monastery. All were captured by the monk when they had come to pray for offspring. ${ }^{97}$ This is a stereotypical theme in gong'an stories. The Longtu gong'an also contains a story about a student who is nearly murdered by monks because he accidentally discovers their secret hiding place for women. ${ }^{98}$ Clearly, even eminent literati such as Wang Tonggui were not above reading and recycling gong'an tales.

The gong'an stories fell quickly out of fashion in the 162 os. Why was this? Literary fashion, like any other fashion, comes and goes. It is difficult to gauge the exact reasons. It might be because the gong'an stories were a bit of "literary fast food." They were cheaply printed and bound. Two early collections were published in Fujian by Yu Xiangdou-a region which, by Ming times, was already notorious for producing poorquality books. ${ }^{99}$ Readers may have been quick to get bored with the stereotypical plots and frequent repetition of stories; once all the familiar themes had been exhausted, the genre naturally fizzled out. But the theme of the lecherous or criminal monk did not fade away with the demise of the gong'an genre. It continued to flourish in different forms and literary genres. The short story collection "Monks and Nuns in the Sea of Sin" (Sengni niehai 僧尼蒘海), devoted entirely to the topic of lustful monks and nuns, was published in the 1620s, soon after the end of the gong'an fashion. ${ }^{100}$ It runs through all the familiar "rapist monk" motifs. Many of its stories overlap with the gong'an stories. ${ }^{101}$

97) Wang Tonggui 王同軌, Ertan 耳談 (Zhengzhou: Zhongzhou guji chubanshe, 1990), 17071.

98) Shōji Kakuitsu, Chūgoku no kōan shōsetsu, 64-80; 388.

99) Hegel, Reading Illustrated Fiction in Late Imperial China, 135-41.

100) Although this book was attributed to Tang Yin 唐寅 (1470-1524), it was actually published in the post-162os.

101) Sengni niehai 僧尼蒘海. Moines et nonnes dans l'océan des péchés, Huang San and Jean Blasse transl., 76-77 (the story about Monk Liaoran); 87-91 (Monk Haichao deceiving a man into believing that his wife is having an affair); 101-5 (similar theme as in the story of monk Haichao); 92-95 (containing several short stories about monks keeping women in a cellar and attempting to kill the person who discovers this secret); 110-13 (two stories similar to the "Wife of Wang Wugong" story in Yijianzhi); 118-24 (monks raping women who come to the monastery to pray for offspring); 125 (two stories about monks raping women who come to pray for offspring); 128-30 (monk keeping a woman in the cellar as a sex slave); 134-36 (mendicant monks forcing a woman to travel with them in disguise of a monk; A travelling monk 
After the 1620s, we find no single collection with such a large proportion of stories about criminal monks, for the simple reason that crime fiction as a whole declined in popularity. However, this does not imply any improvement in the image of monks. Unchaste and lustful monks remained a popular theme of vernacular literature until at least the eighteenth century. ${ }^{102}$ For example, the eighteenth-century novel Yesou puyan 野鼠曝言 contains several “lascivious monk" (yinseng 淫僧) characters. Although the monks are not rapists here, the old "rapist monk" topos has not been forgotten. In one episode, an adulteress feels confident that she can avoid legal punishment should the affair be exposed, as the magistrate would automatically assume that the monk had raped her. ${ }^{103}$

After 1620, gong'an stories were replaced in popularity by Feng Menglong's Sanyan collections, containing huaben stories based on (or inspired by) Song and Yuan originals. Although written in vernacular language, they are more sophisticated, better written, and were available in more expensive editions. Each story contains three elements: a well-written poem, then a short prologue, and finally a similar but longer and more complicated story. The storylines are more compelling and less formulaic than those of the gong'an stories. This probably shows that the Sanyan collections were targeted at a narrower and wealthier group of readers.

The Sanyan collections contain several stories touching upon the theme of the criminal or rapist monk. I have already mentioned that Yushi mingyan 喻世明言 includes the story of Jiantie heshang. The Xingshi hengyan 醒世恒言, another Sanyan collection, also has a story about monks raping women who come to the monastery to pray for offspring. The whole plot is finally exposed by Magistrate Wang with the

cuts off a woman's nipples on the street. The second story is originally from Zhu Yunming's 祝允明 Yeji 野記); 137-39 (monks attempt to kill the scholar who accidently discovered that they are hiding women in the monastery); 140-47 (monks abduct a woman on her way back from her natal family house).

102) Vincent Durand-Dastès, "Désirés, raillés, corrigés: les bonzes dévoyés dans le roman en langue vulgaire du XVIe au XVIIIe siècle," Extrême-Orient, Extrême-Occident 24 (2002): 95-112.

103) Yesou puyan 野鼠曝言 (Beijing: Renmin wenxue chubanshe, 1997), 53-65. 
help of a prostitute pretending to pray. ${ }^{104}$ This is very likely to be a rewriting of the gong'an story cited earlier. ${ }^{105}$

However, the Sanyan collections also contain another group of stories about unchaste monks which are quite different in character to the "lecherous monk" type discussed so far. These stories, which André Lévy has called the "monk and courtesan" type, deal with eminent scholarmonks rather than low-class rascal clerics. The girls (sometimes courtesans) are sophisticated and attractive, unlike the naïve female victims in the gong'an stories. The source of these stories can possibly be traced back as early as, if not earlier than the Song. ${ }^{106}$ They demonstrate a more complex mentality and adopt a more tolerant and sympathetic, although nonetheless critical, attitude towards vow-breaking monks.

Many of these stories involve a girl called Red Lotus (Honglian 紅蓮)—a name with both Buddhist and sexual connotations. ${ }^{107}$ For example, in Yushi mingyan 喻世名言, the eminent monk Five Vows (Wujie 五戒) cannot resist temptation and sleeps with Red Lotus, who has been adopted and raised by his disciple. Wujie then dies while sitting in the lotus position (zuohua 坐化), as eminent monks stereotypically do. Another eminent monk, Mingwu 明悟, decides to follow him in order to help him realize his Buddhist identity in the next life and also passes away. In the next life, Wujie becomes the famous Song poet Su Shi and Mingwu becomes his clerical friend, Foyin 佛印. Foyin is finally able to make Su Shi realize that his vocation is really for Buddhism rather than a bureaucratic career. ${ }^{108}$

Wujie is thus portrayed as eminent but flawed. In the next life, he becomes Su Shi, a great scholar admired for a time by the emperor. It is certainly not a bad reincarnation from the secular perspective. It would

\footnotetext{
104) Feng Menglong, Xingshi hengyan, 39:838-51

105) This is according to Hanan's dating. Hanan, The Chinese Short Stories, 245.

106) For a possible genealogy and detailed analysis of these story, see André Lévy, "Le moine et la courtisane: Formation et évolution d'un thème littéraire d'origine Sung," Études Song: In Memoriam Étienne Balazs Série 2, Civilisation 2, ed. Françoise Aubin (The Hague: Mouton, 1973), 139-58.

107) Ming heshang du Liucui 明和佮度柳翠 and Mingwu chanshi gan Wujie 明悟禪師趕 五戒 in Gujin xiaoshuo, 29, 30; Foyin sidiao Qinniang 佛印四調琴娘 in Xingshi hengyan, 12. 108) Gujin xiaoshuo, 30:471-87. It was a development of the story in the Qingping shantang huaben. Hong Pian, Qingping shantang huaben (Beijing: Wenxue guji kanjingshe, 1955), 4:1-9. For discussion of this story, see Jaroslav Průšek, Chinese History and Literature (Dordrecht: Academia, 1970), 314-16. Also, Lévy, "Le moine et la courtisane."
} 
probably be considered an even better reincarnation for someone with no vocation for Buddhism. For Wujie, however, this is a step down. After his failure to achieve worldly success, and with the help of Foyin, he finally understands who he is. Unlike the simplistic, black-or-white attitude towards clerics and sex in gong'an stories, here we see tolerance, even admiration. Buddhism is esteemed as a religious faith. Religious achievement is portrayed as even more important than bureaucratic success. Wujie is not despised as debauched. He is not a "lascivious monk" (yinseng); his image is not even negative. The message is that eminent monks might also break their vows and be punished, but they are still to be respected.

This group of "monk and courtesan" stories is not typical of Ming and Qing fiction. Their Song and Yuan origins probably explain the higher social prestige that Buddhist monks enjoy in them. ${ }^{109}$ Although the figure of the "saintly but vow-breaking monk" is fairly common in late imperial literature, it is not always the vow of celibacy which is involved. The saintly mad monk Crazy Ji (Jidian 濟癭) and the knight-errant monk Lu Zhishen 魯智深 from Shuihu zhuan 水澈傳 are other typical examples. ${ }^{110}$

Leaving fiction aside, the image of the lascivious monk was deeply rooted in Chinese society up to the end of the Qing. I have mentioned before that "visiting prostitutes" was a cliché used frequently when lodging a legal complaint against a monk. Vincent Goossaert, in his study of anticlerical polemics in the nineteenth-century newspaper Shenbao 申報, points out that breaking the vow of celibacy was one of the three main complaints made against monks. ${ }^{111}$ Although the circulation of Shenbao was mostly limited to the Shanghai and Jiangnan area and its polemic largely reflected intellectuals' disappointment with secondrate clerics, the criticism of unchaste monks (and nuns) must, to some degree, have been influenced by the literary image of lecherous monks.

\footnotetext{
109) Lévy, "Le moine et la courtisane," 140. Also, Durand-Dastès, "Désirés, raillés, corrigés."

110) Both Jidian and Lu Zhishen are "meat-eating and wine-drinking" monks. For discussion of Jidian, see Meir Shahar, Crazy Ji: Chinese Religion and Popular Literature (Cambridge, Mass.: Harvard Univ. Asia Center, 1998), 31-45. Also, Keith McMahon, "The Ascetic Jidian," in Misers, Shrews and Polygamists (Durham: Duke Univ. Press, 1995), 93-96. McMahon discusses the idea that Jidian acts like a sexual trickster, serving as a parody of women.

111) Vincent Goossaert, "Anatomie d'un discours anticlérical: le Shenbao, 1872-1878," special issue of Extrême-Orient Extrême-Occident, ed. Vincent Goossaert, 24 (2002): 113-31.
} 
This kind of anticlerical polemic, also often associated with the prohibition of temple-visiting by women, was common in official handbooks throughout the Qing. ${ }^{112}$

It would seem, in conclusion, that the prevalence of criminal or rapist monks in Ming gong'an stories cannot be taken as a faithful reflection of how clerics were actually perceived. At any rate, Ming and Qing parents would probably not have grown nervous and vigilant when their daughters met monks conducting ritual services at home, in the same way that today's parents might when their children are offered sweets by strangers. This image was a convention of a particular kind of literature. It was developed to meet the needs of the growing market for recreational literature, with its taste for sex, crime, and simplistic black-or-white moral judgments. And though the taste for gong'an stories was fleeting, the literary stereotype of the lustful or unchaste monk was to become a mainstay of late Ming and Qing fiction, expressed at different levels and in different types of literature. The gong'an stories merely presented this stereotype in a particularly intense and exaggerated form.

\section{Male Anxieties about Female Chastity}

The "unchaste monk" figure in the gong'an stories and in late imperial literature more generally, also reflects a deepening male anxiety about the control of women. The female victims in "rapist monk" stories have usually ventured out alone to monasteries or invited monks to their home for ritual services. These women are not seductresses or curious young girls seeking sexual education or enlightenment, like those portrayed in some eighteenth-century French anticlerical stories. They are either naïve or powerless victims of vile monks. But neither are they entirely faultless. They fail to abide by Confucian precepts concerning proper female behavior: they should stay at home, should not receive clerics, and above all should not visit monasteries.

It was, and probably always had been, a common practice in the Ming and Qing for women to participate in religious ceremonies, to invite clerics to hold services at home, and to go to monasteries to pray

112) Vincent Goossaert, "Irrepressible Female Piety: Late Imperial Bans on Women Visiting Temples," Nan nü 10 (2008): 212-41. 
(especially during temple festivals). Nevertheless, the Ming and Qing elite particularly disapproved of female religiosity outside the family home. I have mentioned that sixteenth-century China saw burgeoning literacy, including female literacy. We know that many Ming gentry women were educated in the same way as their brothers, reading the same classics and writing poetry. ${ }^{113}$ The number of women of moderate literacy also expanded. Pertinently, urban life provided more opportunities for women to meet people outside of their kin. This new-found freedom stimulated a strong male anxiety about sexual licentiousness. ${ }^{114}$

One expression of this anxiety was an intensified obsession with female chastity and seclusion. Chastity was virtually sanctified in the Ming and Qing. Widow suicide (expressive of devotion to a deceased husband or even fiancé) was encouraged and praised by the state in the late Ming (though not the Qing). ${ }^{115}$ Matthew Sommer, in his study of Qing rape and adultery law, points out that the punishment for rape during this dynasty was much harsher than before. The female victim's record of chastity was crucial in rape cases. All women were reduced to the status of wives and daughters, that is, the real victims of rape were not the women themselves but their male relatives, husbands or fathers. ${ }^{116}$

Furthermore, the idea that the only place for a woman was in her patrilineal kinship group was hammered home relentlessly. Zhou Yiqun points out that, with the rise of "Confucian ritualization," the elite (idealistically) adopted the view that female religiosity should be expressed only within a woman's patrilineal kin group. ${ }^{117}$ Women were supposed to play a key ritual role in ancestor worship in their husbands' families. Essays by Qing literati extolling female exemplars flourished. It was argued that there should be no need for a wife and daughter-in-law to pray

113) For a detailed discussion, see Writing Women in Late Imperial China, ed. Ellen Widmer and Kang-I Sun Chang (Stanford: Stanford Univ. Press, 1997).

114) Susan Mann, Precious Records: Women in China's Long Eighteenth Century (Stanford: Stanford Univ. Press, 1997), 194-97.

115) For scholarship on widow suicide in Ming and Qing China, see T'ien Ju-K'ang, Male Anxiety and Female Chastity: A Comparative Study of Chinese Ethical Values in Ming-Ch'ing Times (Leiden: Brill, 1998).

116) Matthew Sommer, Sex, Law, and Society in Late Imperial China (Stanford: Stanford Univ. Press, 200o), 72-76.

117) Yiqun Zhou, "The Hearth and the Temple: Mapping Female Religiosity in Late imperial China, 1550-199o," Late Imperial China 24.2 (2003): 109-55. 
to the Buddha, since parents-in-law should be venerated like Buddhas. Receiving clerics (male or female) at home was inadvisable but going out to monasteries and temples was much worse. A woman should not indulge in such behavior even if her mother-in-law does so (despite the latter being venerated like a Buddha!). ${ }^{118}$ That, presumably, is why women who go to monasteries, even to pray for offspring - fulfilling their duty as wives and daughters-in-law - are punished by being raped by monks. Furthermore, as Beverly Bossler shows, although the birth family played an important role in a woman's life, by late imperial times female filial piety was conceived as primarily patrilineal — that is, directed towards parents-in-law. ${ }^{119}$ Perhaps this is the reason we read so many stories about women being raped when journeying alone to or from their birth family home after quarrelling with their husbands. This dire fate served as fitting punishment for women who had run away from their "true," that is, patrilineal families.

Monks (particularly Buddhist monks) were obvious targets in rape stories, not only because their vows of celibacy made them vulnerable to charges of hypocrisy but also because they had uniquely easy access to women's quarters. As mentioned, women commonly received clerics at home, although the practice was frowned on by the elite. And Ming and Qing laws forbidding women to visit temples were seldom enforced. ${ }^{120}$ The elite complained constantly about women going out during temple festivals and mixing with men. ${ }^{121}$ The early Qing novel, Dengcao heshang 燈草和侉, tells the story of a monk who, by transforming himself into a wick in a lamp, is able to live in the women's boudoir. During the day he remains as tiny as a wick, but by night he becomes as big as a man. Hence, he passes unnoticed and has sexual relations with the mother, daughter, and servant girl of the family. ${ }^{122}$ Stories about monks hidden in women's quarters, or in female disguise, abound. ${ }^{123} \mathrm{Al}-$

\footnotetext{
118) Ibid.

119) Beverly Bossler, “'A Daughter is a Daughter All Her Life': Affinal Relations and Women's Networks in Song and Late Imperial China,' Late Imperial China 21.1 (2000): 90-91.

120) For a discussion of the ban on temple-visiting by women, see Goossaert, "Irrepressible Female Piety."

121) For example, Gongcheng congzhenglu 共城從政錄, in Guanzhenshu jicheng, 43-44.

122) Dengcao heshang 燈草和厼 (Xining: Qinghai renmin chubanshe, 1996).

123) For example, Sengni niehai. Moines et nonnes dans l'océan des péchés, Huang San and Jean Blasse transl., 110-13.
} 
ternatively, monks are shown keeping women disguised as men. Mendicant monks dressing women in monks' robes and taking them travelling with them is a common storyline. ${ }^{124}$ Such stories seem to reflect an anxiety about the blurring of sexual boundaries. Perhaps the implication is that monks straddle the line between femininity and masculinity-they are not "real" men. Nevertheless, monks (especially Tibetan monks) are often portrayed in the vernacular literature as having incredible sexual prowess. The attitude was mixed, then, including both contempt for and fear of monks' sexuality.

This male anxiety was not limited to keeping women away from male clerics. Female clerics, i.e. nuns, also fell under suspicion. Often in literature, nuns function as brokers, pimping women from good families to their lovers, who are not necessarily monks. ${ }^{125}$ The derogatory social category sangu liupo 三姑六婆 took shape in the Ming, comprising low-status female professions which were taboo for women from good families. ${ }^{126}$ Nuns (Buddhist and Daoist) were included, alongside matchmakers, mediums, midwives, procuresses, healers, and brokers. Such women were thought to be vicious, money-grubbing, and devoid of the female virtues. Nevertheless, women from good families unavoidably had close contact with these specialists from time to time and may have established some kind of friendship with them. For example, a pious laywoman might befriend the nuns who came to attend religious services; or a mother arranging her children's marriages might choose a particular matchmaker to work with and would enjoy gossiping with her. Men in respectable families were worried that these low-class women might have a bad influence on their women, bringing disgrace on their family. In stories about wayward nuns, the male authors always warn the readers to be wary of these women. As mentioned above, female literacy increased markedly in late imperial times. Some gong'an stories might have been addressed to female readers, warning them to be cautious about inviting nuns home or befriending them.

Nuns sleeping with men was less a source of concern. We even encounter stories about liaisons between scholars and female clerics

124) Other courtroom collections are Lütiao gong'an, Longtu gong'an, Xiangqing gong'an, and Lianming gong'an. Quoted in Shōji Kakuitsu, Chügoku no kōan shōsetsu, 388-89.

125) Pai'an jingqi, 6:1-27.

126) Goossaert, "Anatomie d'un discours anticlérical," 118. 
recounted in an admiring tone. For example, a late Ming novella collection, the Wanjin qinglin 萬錦情林, records a story about a romance between a talented female cleric and a Confucian student, Pan Bizheng 潘必正. He falls in love with the beautiful and clever Daoist nun, Chen Miaochang 陳妙常, when he is living in a monastery for study. The story has a happy ending, with Chen being allowed to return to the laity and to marry Pan. ${ }^{127}$ This story was very well-known and was turned into a play as well. This is quite different from male fear of vampiric fox-spirits in the guise of beautiful women, contact with whom might lead to physical destruction through loss of life-force. A sexually voracious nun could only harm men in the normal way, as a young and beautiful courtesan might do. ${ }^{28}$

Chen was an exception, however; we do not encounter attractive nuns very often in late imperial vernacular literature. Nuns are usually portrayed as old, greedy, and lovers of gossip. They might sometimes be portrayed as lustful, but they are rarely physically attractive. This might be because, with their tonsure, nuns did not seem particularly attractive to men, although they might make a good pair with lustful monks in stories. ${ }^{129}$ The unflattering image of nuns (both physically and morally) also sprang from an anxiety that they would harm "good women" by luring them out of their boudoirs. The above-mentioned Sengni niehai contains such a nun character who is said to have an extremely large vagina. She introduces her own lover, a monk called Fengshi with a huge member, to the wife of Li Yaqing. ${ }^{130}$ The physical repulsiveness of the nun and her sexual relationship with the monk marks her as a figure of comedy. It is not a nuns' sexuality that poses a threat to men, but their bad influence on women of good families.

In conclusion, male anxiety about female clerics had more to do with their exerting a pernicious influence on "good women" than with their violation of monastic rules (bushou qinggui 不守清規) 一 a common criticism of monks. ${ }^{131}$ This confirms that, to a large degree, mistrust of

\footnotetext{
127) Sun Kaidi 孫楷第, Zhongguo tongsu xiaoshuo mulu (wai'erzhong) 中國通俗小說目 錄 (外二種) (Beijing: Zhonghua shuju, 2012), 308.

128) A typical example is Xingshi hengyan, 15 .

129) Sengni niehai contains a section on "nuns". They mostly sin with monks rather than laymen: Moines et nonnes dans l'océan des péchés, Huang San and Jean Blasse transl, 163-204. 130) Ibid., 45-57.

131) Ibid.
} 
clerics was driven by men's anxiety about keeping their women safe. They worried that monks might steal their women and nuns might undermine their virtue.

\section{Concluding Remarks}

The negative portrayal of Buddhist monks and nuns in Ming gong'an stories has often been interpreted, particularly in Chinese scholarship, as evidence for a so-called "decline of Buddhism" in the late imperial period. ${ }^{132}$ This thesis needs serious qualification. It is true that the low social status of non-elite clerics, who were commonly poor and relatively uneducated, made them vulnerable to irreverent and even contemptuous treatment. Derogatory terms such as "bald donkey" (tulü 秃驢) or "bald bandit" (zeitu 賊秃) were commonly used to refer to monks. But the gong'an stories I have surveyed are directed entirely against individual members of the clergy, not against the clergy as a whole or against Buddhism as a religion. In this respect, they are very different from eighteenth-century European anticlerical fiction, which is directed both against the Church as an institution and (in many cases) against Christian doctrine itself.

Indeed, it is misleading to describe the Ming gong'an stories as "anticlerical" at all, since their primary purpose is not to discredit the clergy. Rather, it is to fulfil a certain need of the contemporary book market, or to give vent to male anxiety over the behavior of women. There is no lack of positive clerical images in other types of vernacular literature. Significantly, the writings of contemporary scholarly monks never mention clerics as suffering from a bad reputation. ${ }^{133}$ So while the low social status of non-elite clerics in the Ming can be seen as a background condition for the emergence of this kind of literature, it was not a sufficient cause; other, more immediate forces were also at work.

\footnotetext{
132) For example, see Lin Cuiyao 林璀瑤, “Jian, xie, yin, dao."

133) I have consulted several collections of late Ming scholarly monk stories, including Hanshan Deqing 惎山德清, Hanshan laoren mengyouji 敗山老人夢遊集 (Shanghai: Shanghai guji chubanshe, 1995); Yunqi Zhuhong 雲棲袾宏, Zizhilu 自知錄 (Nanjing: Jinling kejingchu, 1899); Yunqi Zhuhong, Yunqi fahui 雲棲法彙 (Nanjing: Jinling kejingshu, 1899); Yunqi Zhuhong, Zhuchuang suibi 竹窗隨筆 (Shanghai: Shangwu yinshuguan, 1912-1949); Zibo Zhenke 紫柏真可, Changsong rutui 長松茹退 (Jinan: QiLu shushe, 1997).
} 


\begin{abstract}
Buddhist monks were commonly portrayed as seducers and even rapists in late sixteenth-century vernacular literature, including, most commonly, courtroom tales (gong'an 公案). Do these stories reflect a deterioration in clerical morality and behavior, or a decline in Buddhist faith and practice, as is sometimes argued? Neither explanation is credible. I argue that the image of monks in courtroom tales should be understood as a literary convention, growing out the burgeoning market for entertainment literature, rather than a window onto social reality. It also reflects an increasing male anxiety about the control of women.
\end{abstract}

\title{
Résumé
}

La littérature vernaculaire de la fin du seizième siècle et notamment les romans judiciaires (gong'an 公案) a fréquemment dépeint les moines bouddhistes comme des séducteurs voire des violeurs. Ces récits reflètent-ils une détérioration des mœurs et de la moralité cléricale, ou encore un déclin de la foi et de la pratique bouddhique, comme le veut une explication parfois avancée? Aucune de ces deux thèses n'est crédible. L'article montre que l'image des moines dans les romans judiciaires doit être comprise comme une convention créée par un marché de la littérature de divertissement alors en plein essor, plutôt que comme un écho de la réalité sociale. Elle exprime de plus une anxiété croissante chez les hommes au sujet de la difficulté de contrôler les femmes de leur famille.

\section{提要}

在包括尤其是公案在內的十六世紀晚期的白話文學中, 佛教的僧人經常 被描寫成色誘者, 甚至是強姦犯。這些故事是否如有些學者所論述的那 樣, 反映了僧職品行的墮落, 亦或說佛教信仰與實踐的衰敗? 本文認爲這 兩種解釋都缺乏信服力。相反, 本文認爲公案小說中僧人的形象應被視 爲一種文學典型。其緣由應被追溯到娛樂文學市場的迅速發展, 而非社會 現實。這種類型化的描述同時也反映了男性在控制女性方面㸝發強烈的焦 慮感。

\section{Keywords}

Buddhist monks - gong'an stories - vernacular literature - anticlericalism - sex crimes 